\title{
Phytochip: Development of a DNA-microarray for rapid and accurate identification of Pseudo-nitzschia spp and other harmful algal species
}

\author{
Noyer Charlotte ${ }^{1,2,3,4}$, Abot Anne ${ }^{2,3,4}$, Trouilh Lidwine ${ }^{2,3,4}$, Anton Leberre Véronique ${ }^{2,3,4}$, \\ Dreanno Catherine ${ }^{1,}$
}

${ }^{1}$ IFREMER, centre Bretagne, Laboratoire Detections, Capteurs et Mesures, F-29280 Plouzané, France

${ }^{2}$ Université de Toulouse, INSA, UPS, INP, LISBP, F-31077 Toulouse, France

3 INRA, UMR792, Ingénierie des Systèmes Biologiques et des Procédés, F-31400 Toulouse, France

${ }^{4}$ CNRS, UMR5504, F-31400 Toulouse, France

* Corresponding author : Catherine Dreanno, email address : catherine.dreanno@ifremer.fr

\begin{abstract}
:
Detection of harmful algal blooms has become a challenging concern because of to the direct impacts on public health and economy. The identification of toxic dinoflagellates and diatoms in monitoring programs requires an extensive taxonomic expertise and is time consuming. Advances in molecular biology have allowed the development of new approaches, more rapid, accurate and cost-effective for detecting these microorganisms. In this context, we developed a new DNA microarray (called, Phytochip) for the simultaneous detection of multiple HAB species with a particular emphasis on Pseudo-nitzschia species. Oligonucleotide probes were designed along the rRNA operon. After DNA extraction, the target rDNA genes were amplified and labeled using an asymmetric PCR; then, the amplicons were hybridized to the oligonucleotide probes present on the chips. The total assay from sea water sampling to data acquisition can be performed within a working day. Specificity and sensitivity were assessed by using monoclonal cultures, mixtures of species and field samples spiked with a known amount of cultured cells. The Phytochip with its 81 validated oligonucleotide probes was able to detect 12 species of Pseudo-nitzschia and 11 species of dinoflagellates among which were 3 species of Karenia and 3 species of Alexandrium. The Phytochip was applied to environmental samples already characterized by light microscopy and cloned into DNA libraries. The hybridizations on the Phytochip were in good agreement with the sequences retrieved from the clone libraries and the microscopic observations. The Phytochip enables a reliable multiplex detection of phytoplankton and can assist a water quality monitoring program as well as more general ecological research.
\end{abstract}




\section{Highlights}

- We developed a microarray for HAB species identification with a particular emphasis on Pseudonitzschia. Pseudo-nitzschia species identification by microarray was compared to cloning and sequence analysis. The DNA microarray enables accurate multiplex identification at low concentration. The DNA microarray will improve the performance of the monitoring program

Keywords: $\mathrm{HAB}$, Pseudo-nitzschia, microarray, ribosomal oligonucleotide probes, environmental monitoring 


\section{Introduction}

Monitoring Harmful Algal Blooms (HAB) has become a major challenge in managing coastal areas. It has been motivated by both economic and health impacts (Trainer et al., 2012). Thus, characterizing phytoplankton communities is essential and has become an obligation for different coastal regions in the world. In the European Union, member states have to clearly monitor shellfish production areas and detect the presence of toxins produced by phytoplankton species (Karlson et al., 2010). Along French coasts and in the English Channel, recurrent toxic events were attributed to Pseudo-nitzschia blooms and impacted significantly the fishery and shellfish economy. In this diatom genus, toxigenic and nontoxigenic species can co-occur, therefore, it is crucial to discriminate the various Pseudonitzschia taxa co-occurring within a phytoplankton assemblage to clearly evaluate a potential toxic event and to understand also the dynamics of the toxic bloom. Whereas the total phytoplankton biomass is relatively easy to evaluate (i.e. by the estimation of chlorophyll concentrations or by counting using microscopy), the difficulties, which face monitoring programs are related to the identification and quantification of individual species (Galluzzi et al., 2011).

Traditionally, phytoplankton monitoring has been performed by identification and enumeration using optical microscopy; however a precise identification is not always possible (Kaczmarska et al., 2007; Karlson et al., 2010; Lelong et al., 2012). Given the morphological similarities between different species and the morphological variability within a single species (Lelong et al., 2012; Orr et al., 2011; Brand et al., 2012), light microscopy alone is often insufficient to assess the potential toxicity of coastal water blooms (McCoy et al., 2013). For example, it is nearly impossible to assess the species-specific identification especially for cryptic species in the Pseudo-nitzschia genus (Penna and Galluzzi, 2013). Moreover, these 
practices require highly trained taxonomists and are labor and time consuming. They are inappropriate when a large number of samples has to be routinely examined. Because of the weaknesses and limitations of the classical methods, several molecular biological methods based on the DNA sequences have been developed in the last decade for the accurate identification of phytoplankton (Ebenezer et al., 2011). These alternative methods are in general based on DNA probe hybridization (i.e fluorescence in situ hybridization (FISH) on fixed cells (Scholin et al., 1997) or sandwich hybridization assay (SHA) on lysed cells, on qPCR techniques (McDonald et al., 2007; Andree et al., 2011; Penna and Galluzzi, 2013), nucleic acid sequence-based amplification (NASBA) (Ulrich et al., 2010; Delaney et al., 2011), isothermal amplification (Zhang et al., 2014), Automated Ribosomal Intergenic Spacer Analysis (ARISA) (Hubbard et al., 2008), on microarrays (Gescher et al., 2008a and 2008b; Galluzzi, et al., 2011; Smith et al., 2012; Edvardsen et al., 2013; McCoy et al., 2013, Wollschlager et al., 2014) and recently next generation sequencing (Cooper et al., 2014)

For routine monitoring purposes, a method should be user-friendly, high-throughput, rapid and present multiplexing capabilities. Real-time quantitative PCR has been developed to identify and quantify some toxic dinoflagellates (Zhang et al., 2014; Smith et al., 2014; Hariganeya et al., 2013; Kavanagh et al., 2010; Touzet et al., 2009) and a few diatoms (Penna et al., 2013; Andree et al., 2011). Even if q-PCR methods appear to be the gold standard in terms of sensitivity, this approach alone may not be well adapted for monitoring rapidly a large panel of toxic algae, in a single experiment. One q-PCR reaction allows handling only single or a few target species at the same time, in the case of a multiplex PCR. But for genetically close species, multiplex PCR is difficult to develop. As a consequence, several distinct assays would thus be needed in order to obtain a complete view of the phytoplankton 
composition in a single sample. This will drastically increase the costs and the time required for the analysis.

In addition to miniaturization, the real key advantage that microarray technology has over PCR-based technologies is their high multiplexing capability (Scheler et al., 2014). DNA microarrays are believed to have the potential of identifying hundreds of species in parallel and to differentiate them among a large number of related species. Over the last few years, the phylochips, microarrays dedicated to taxonomic investigation, have been highly developed to detect and identify various organisms such as cereals (Rønning et al., 2005), microbes (Gentry et al., 2006; Warsen et al., 2004; Franke-whittle et al., 2009; Janse et al., 2012), fishes (Kochzius et al., 2010) and phytoplankton (Gescher et al., 2008a and 2008b; Scorzetti et al., 2009; Metfies et al., 2010; Galluzzi et al., 2011; Smith et al., 2012; Barra et al., 2013; Edvarsen et al., 2013; McCoy et al., 2013); all in highly complex samples.

For microorganism diagnostics, the use of DNA shows several advantages over RNA. DNA is much more stable than RNA, and can easily be isolated without any degradation from frozen, fresh or preserved samples. It is important to be able to analyze seawater samples fixed with lugol solution, the standard process in toxic phytoplankton monitoring programs. Another advantage is that also metabolically inactive organisms can also be detected. Within the MIDTAL project (http://www.midtal.com), several microarrays were set up to detect at the transcript level the main toxic microalgae. These microarrays, which are patented, target quantitatively rRNA, but the approach seems to be difficult to set up for identifying Pseudonitzchia and Dinophysis species because of the lack of probe specificity (Barra et al., 2013; Edvardsen et al., 2013).

The objectives of the present study were to develop and validate a user-friendly DNAbased microarray for the identification of the main harmful marine microalgae species 
detected along the French European coasts. This biochip requires only basic hybridization and scanning equipment and new probe designs can be introduced easily and quickly when compared to the manufactured high density microarrays. The Phytochip was developed on Dendrislides; the advantages of these G4-dendrimer-coated slides are their high binding capacity because of the increased number of reactive sites to which probes can be covalently bound, their better accessibility to targets as well as their good quality, accuracy and reliability with low background (Le Berre et al., 2003; Trevisiol et al., 2003, 2009). This study describes the development and optimization of the "Phytochip" targeting various toxic microalgae with strong emphasis on Pseudo-nitzschia diatom species, responsible for recurrent shellfish poisoning in France. The Phytochip was subsequently used to monitor the temporal distribution of the Pseudo-nitzschia species in the Bay of Concarneau. Clone libraries were also constructed and sequenced. The observed pattern by the microarray was then compared to those given by the molecular sequences of the clone libraries and by the traditional standard optical microscopy procedure.

\section{Materials and methods}

\subsection{Probe design}

Oligonucleotide probes were designed using the ARB software (Ludwig et al., 2004) on aligned rRNA sequences found in the SILVA databases (Pruesse et al., 2007); the Small Subunit, 18S (SSU Ref_108_SILVA_09_09_11) and the Large Subunit, 28S (LSU Ref_108_SILVA_16_08_11). The rDNA ITS sequences were retrieved from the public databases (http://www.ncbi.nlm.nih.gov/guide/dna-rna/). The probe-design-function implemented in ARB was used with minimal (or none) non-target hits (number of non-target 
species liable to be detected by the probe) and maximal target hits $(>95 \%)$ in order to design highly specific probes. Additional probes were designed with the FastPCR software (Kalendar et al., 2011). We aimed at selecting oligonucleotide probes with homogenous behavior; therefore, probes were designed according to the following 6 criteria: 1) length $25 \pm 2 \mathrm{bp} ; 2$ ) melting temperature $(\mathrm{Tm}) 55^{\circ} \mathrm{C}$ based on SantaLucia's table of thermodynamic parameters from Primer3Plus (Untergasser et al., 2007); 3) GC content "around" 50\%; 4) limited secondary structures checked with Primer3Plus and Oligo Analyzer (http://eu.idtdna.com/analyzer/Applications/OligoAnalyzer/); 5) If mismatches with nonspecific targets occurred, these were located in the center of the probes (Letowski et al., 2004; 6) General oligonucleotide "quality" was over $80 \%$ according to FastPCR. Potential probes were tested in silico 1) using the probe match tool from ARB against their respective ARB databases (SILVA databases for the $18 \mathrm{~S}$ and $28 \mathrm{~S}$ designed probes, and our databases containing over 2500 ITS phytoplankton sequences from various genera retrieved form public databases (EMBL/GenBank//DDBJ); 635 of them belonging to Pseudo-nitzschia species) 2) using the probe-match function against the Ribosomal Database Project (http://rdp.cme.msu.edu/probematch/search.jsp), and 3) using BLAST searches against the GenBank nucleotide database (Altschul et al., 1990). The most specific and thermodynamically stable oligonucleotide probes were selected or modified to complete the requirements defined above. For this purpose, length or position of the probe was adjusted by the addition or removal of nucleotides at either end. Then, probes were checked again by a Primer-Blast to guarantee target specificity (Ye et al., 2012). A hierarchical probe set targeting different taxonomic levels was constructed. (Metfies and Medlin, 2008). Several probes (up to 4) per species were selected in order to limit false positive or negative signals. 


\subsection{DNA Extraction and PCR Amplification}

The phytoplankton strains were cultured using the f/2 Guillard and Ryther medium under optimal temperatures with $150 \mu \mathrm{mol}$ photons $\mathrm{m}^{-2} \mathrm{~s}^{-1}$ from a cool-white fluorescent light with a 14:10 LD photoperiod (Andersen, 2005). The cells were harvested by centrifugation (5000 g, $10 \mathrm{~min}$ ) and then washed three times in PBS (phosphate buffer saline) before the genomic DNA was extracted either using a $10 \%$ CTAB extraction procedure (Murray and Thompson, 1980) or with the DNAeasy Plant Mini Kit (Qiagen, Germany) according to the manufacturer's instructions. All DNA concentrations were measured with a NanoDrop spectrophotometer (ThermoFisher, USA) and DNA was stored at $-20^{\circ} \mathrm{C}$. The DNA from the cultures (10 to $30 \mathrm{ng} /$ reaction) was amplified by an asymmetric PCR reaction (Janse et al., 2012). Fifty microliter reaction mixtures consisted of $1 \mathrm{X}$ Flexi-Promega Buffer, $200 \mu \mathrm{M}$ of dNTPs, $3.5 \mathrm{mM}$ of $\mathrm{MgCl}_{2}, 1.25 \mathrm{u}$ of GoTaq ${ }^{\circledR}$ DNA polymerase (Promega, USA) with $0.5 \mu \mathrm{M}$ 5'-labelled Cy5 forward primer, and $0.1 \mu \mathrm{M}$ reverse primer. We used generic primers previously designed for phytoplankton studies (Lenaers et al., 1989; Metfies and Medlin, 2007, 2008; White et al., 1990) as well as generic primers we developed specifically for the Pseudo-nitzschia genus (Table 1). The specificity of the new primers (PSN_F1 and PSN_R1) was tested in silico and in vitro by PCR using monoclonal cultures or single phytoplankton cells (Table S1). The PCR protocol consisted of $5 \min 94^{\circ} \mathrm{C}$ for $5 \min (1 \mathrm{x}) ; 35$ cycles consisting of $\left(30 \mathrm{sec}\right.$ at $94^{\circ} \mathrm{C} ; 1 \mathrm{~min}$ at the primer-specific annealing temperature, and $1 \mathrm{~min}$ at $72^{\circ} \mathrm{C}$ ) ; and a final elongation of $5 \mathrm{~min}$ at $72^{\circ} \mathrm{C}$. PCR amplicons were analyzed on $1 \%$ agarose gels and purified with the MinElute PCR Purification Kit (Qiagen, Germany). The quantity of purified products and Cy5 incorporation were measured using a Nanodrop spectrophotometer (ThermoFisher, USA). It should be noted that this PCR step was not only 
to amplify the genomic material, but also to eliminate non-specific hybridization due to the non-target sequences of the genomic DNA.

\subsection{Microarray Hybridizations}

Dendrislides (Dendris ${ }^{\mathrm{TM}}$ Diagnosis Designer, France) were used for spotting the microarrays. Dendrimer G4 was employed to generate an amino-silanised glass surface onto which $\mathrm{NH}_{2}$-modified DNA probes were covalently fixed by their 5'ends (Le Berre et al., 2003, Trevisiol et al., 2003, 2009). A spotting robot Q-Array Mini (Genetix(C) was used to spot the oligonucleotide probes with a 5'-amino-C6-modification (Sigma Life Science, France) onto the slides in duplicates at a final concentration of $75 \mu \mathrm{M}$ in $0.15 \mathrm{M}$ sodium phosphate buffer ( $\mathrm{pH}$ 8.4). Positive and negative controls were spotted onto the slide. Two types of negative controls were used: spotting of pure buffer and an oligonucleotide that does not target phytoplankton sequences (Gescher et al., 2008a). Two positive probes were spotted on the microarray slide, both from the influenza A virus hemagglutinin sequence (5'GCGACAGTTGAGTAGATAGCCAGAATC-3’ and 5'AGATAGCCAGAATCCGATAGACCCC-3') and for which a complementary sequence fragment was mixed into the sample before the PCR step. An anchoring Cy3-labelled DNA was also spotted on both sides of each block of the microarray to facilitate grid alignment for analysis.

To provide enough time for covalent binding between the oligonucleotide and the dendrislide surface, the microarray slides were maintained overnight in a humid chamber, and then subjected to a reduction of the imine functions by incubating them for $3 \mathrm{~h}$ with $3.5 \mathrm{mg}$. $\mathrm{mL}^{-1}$ sodium borohydride solution, rinsed with milliQ-filtered water and dried by cytocentrifugation. The dendrislides were then stored at $4^{\circ} \mathrm{C}$ until use. Fluorescently labeled 
amplicons (250 ng) were diluted in the hybridization mix (SSC 4X, SDS $0.2 \%, 0.1 \mathrm{mg} / \mathrm{mL}$ salmon sperm DNA), denatured at $92^{\circ} \mathrm{C}$ for 2 min and then loaded into an Agilent gasket with 8-microarray positions per slide. Hybridization was performed at $65^{\circ} \mathrm{C}$ for $30 \mathrm{~min}$ in an Agilent microarray chamber. The slides were subsequently washed for $1 \mathrm{~min}$ in $2 \mathrm{X} \mathrm{SSC} / 0.2 \%$ (V/V) SDS and for $1 \mathrm{~min}$. in $0.2 \mathrm{X} \mathrm{SSC}$, and finally dried with a cyto-centrifuge.

The hybridization signals were quantified as arbitrary units on an Innoscan 900 laser scanner at $635 \mathrm{~nm}(\mathrm{Cy} 5)$ as well as $535 \mathrm{~nm}$ (Cy3) (i.e. grid alignment spots). The fluorescence signal was analyzed with the MAPIX software (Innopsys, France). The fluorescent signal (FS) of a probe is obtained by calculating the arithmetical means of the intensity median after subtraction of the background noise (directly obtained from the MAPIX software) (He and Zhou, 2008). A minimal fluorescence threshold value was determined as $1 \%$ of the highest oligonucleotide probe signal of the chip validated with the DNA samples extracted from monoclonal phytoplankton cultures. A signal was considered positive when the fluorescence was higher than this arbitrary threshold. Furthermore, two positive controls were set up to assess the PCR amplification, labeling and hybridization process. DNA fragments corresponding to the influenza A virus hemagglutinin gene sequence (1730 bp) were constructed with at their $5^{\prime}$ and $3^{\prime}$ end the complementary sequences of two primer couples (ITS1/ITS4 and PSN-F1/PSN-R1). These were mixed into the samples before the PCR step. The specificity of these control probes was assessed on different microalgal rRNA amplicons and no cross-hybridization could be observed.

\subsection{Microarray Performance}

Probe specificity was first investigated by hybridization of PCR products from the monoclonal algal culture DNA (Table S1). Each species was tested at least in triplicate using either 3 different strains or with 3 independent PCR experiments, in the case that only one 
strain of a species was available. Preliminary results revealed a much higher specificity with the ITS probes, and a lot of cross-hybridization with the 18S rRNA probes for Pseudonitzschia. For this reason, we decided to focus our efforts on ITS probes for the identification of Pseudo-nitzschia species. Once the best probes identified, a hierarchical identification key was established from the genus up to the species. We can use this simple way of scoring as all cross-hybridizing probes were eliminated during the development of our test. A species is thus present if there are signals with the probes from its genus, clade and species level. Then, other validations were investigated by using mixed genomic DNA of Pseudo-nitzschia and other dinoflagellate species (species multiplex).

To get insight in the Phytochip sensitivity, cultures of A. minutum and P. delicatissima were used to spike seawater samples collected at Saint Anne du Porzic (48²1 'N; $4^{\circ} 33^{\prime}$ W; Brittany, France) $100 \mathrm{ml}$ of environmental sea water was spiked with approximately 500, 1000, 5000, 10000, and 25000 A. minutum cells/L, and 5000, 10000, 25000, 50000 and 100000 P. delicatissima cells/L. These samples were filtered onto Isopore membranes with a pore size of $1.2 \mu \mathrm{m}$ (Millipore, Germany). Filters were shock-frozen in liquid nitrogen and stored at $-80^{\circ} \mathrm{C}$. Subsequently, DNA was extracted from the filters and amplified by an asymmetric PCR using the 5'-labelled Cy5 forward (28S or ITS) and reverse (28S or ITS) primers (for A. minutum and P. delicatissima respectively). Amplicons were then purified and Phytochip-tested.

\subsection{Phytochip Validation with Environmental Samples}

Six samples were collected monthly in the Bay of Concarneau $\left(47^{\circ} 49^{\prime} \mathrm{N}, 3^{\circ} 57^{\prime} \mathrm{W}\right.$; Brittany, France) from March to July 2012. An additional sample was taken at the end of June because the highest abundances of Pseudo-nitzschia occurred at this time. Water samples 
were taken from the sea surface using an $8 \mathrm{~L}$ Niskin bottle. $100 \mathrm{~mL}$ of this seawater was used for microscopic cell counts and preserved within acidic lugol's iodine solution. Fixed phytoplankton samples were counted according to the method of Utermöhl (Karlson et al., 2010). Additionally, $100 \mathrm{~mL}$ sea water was vacuum filtered through an Isopore membrane (Millipore, Germany) with a pore size of $1.2 \mu \mathrm{m}$. Filters were shock-frozen in liquid nitrogen and stored at $-80^{\circ} \mathrm{C}$. Sample extraction and preparation followed the protocol described above (see $\S 2.2$ and 2.3).

In order to test the specificity of the Pseudo-nitzchia genus primers and validate the microarray in vivo, clone libraries were constructed from these environmental samples and the individual clones sequenced. These results were compared to those obtained by the Phytochip and light microscopy identification. In short, the ITS rDNA gene was amplified using the PSN_F1 x PSN_R1 primers. The purified amplicons were then cloned into the pCR2.1 TOPO vector and transformed into Top10 chemo-competent Escherichia coli cells (Invitrogen, USA). The clones were Sanger sequenced by MilleGen (France) and GATC Biotech AG (Germany). Sequences were checked and aligned using BioEdit v7.1.3.0 (Hall et al., 1999). Affiliations were confirmed by BLAST and ARB analyses. Sequences were added in our ARB database and inserted into the tree using the maximum parsimony criterion.

Regarding the microarray results, one probe per species was defined as the speciesreference probe, which is the probe showing the highest signal. We calculated the ratio between the FS from the species reference probes and the FS from the PSN_genus_Hf20 probe to standardize values and to be able to compare the evolution of relative proportions of Pseudo-nitzchia species between samples,

\section{Results}




\subsection{Oligonucleotide Probe Design and Specificity of the Phytochip}

284 oligonucleotide probes were initially designed (18S rDNA: 107; ITS rDNA: 164 and 28S rDNA: 13) to target several harmful algal genera and species with a particular interest in detecting and identifying Pseudo-nitzschia species. Thus, 109 oligonucleotide probes were dedicated to 18 Pseudo-nitzschia species. In our study, a series of 81 probes was finally validated to unambiguously and hierarchically identify 12 Pseudo-nitzschia species and 11 Dinoflagellate species (Table S2). Except for the Alexandrium genus, the oligonucleotide probes designed on the 18S rRNA gene showed a great deal of crosshybridization and were not specific in comparison with the ITS or $28 \mathrm{~S}$ probes. A panel of strains was used to validate the oligonucleotide probes from the phytochip; although not all species could be tested, because of the lack of monoclonal cultures or genomic DNA from these species. The principal genera of HAB species such as Alexandrium, Karenia and Pseudo-nitzschia could be detected with $28 \mathrm{~S}$ and ITS probes The use of a hierarchical design as well as the design of several different probes per species (a set of probes) allowed the correct identification of 12 species of Pseudo-nitzschia (Fig. 1 and Table S2A). A crosshybridization of the probes PSN_seriata_ITS _ 8 with its closest relative, the P. australis species, was observed, but FS was lower for P. australis than for P. seriata. Moreover, when P. australis was present, the 2 oligonucleotide probes designed for it (i.e PSN_austr5-2m and PSN_australis5m) give a high and specific signal.

We defined up to 5 specific probes for the specific detection of the various dinoflagellates such as Azadinium spinozum, Lingulodinium polyedrum, Ostreopsis ovata, Karenia brevis, Karenia mikimotoi, Karenia selliformis, Prorocentrum micans (Table S2B) and 3 Alexandrium species (A. catenella, A. tamarense and A. minutum; Table S2C). Alexandrium tamarense and A. catenella are closely related species that were only 
discriminated by the probes designed on the 28S rDNA gene sequence. Alexandrium minutum can be identified with the probes designed on the $18 \mathrm{~S}$, ITS region and $28 \mathrm{~S}$ rDNA gene sequences (Table 2 and S2C).

The main interest of using DNA microarrays lies in multiplex detection when identifying and classifying accurately and straightforwardly species in mixtures. The results obtained from the 10 mixture samples (6 Pseudo-nitzschia mixtures and 4 dinoflagellates mixtures) were in agreement with their respective composition (Table 3A and B). None or very little FS below threshold was observed with probes from the absent species (Table 3A and B). In our experiments, we co-amplified and detected successfully up to 7 species simultaneously (we did not test more species in mixture) with the Phytochip. Nonetheless, some differences in probe FS appeared when comparing species in simplex and multiplex assays. For example, when we removed $P$. australis from the Pseudo-nitzschia mixture, $P$. seriata specified by 2 clade-probes (PSN_seriataGrp_f10 and PSN_seriataGrp_f4) and one species probe (PSN_seriata_ITS_8) was barely detected whereas the 2 clade probes reached saturation in simplex (Table $3 \mathrm{~A}$ and $\mathrm{S} 2 \mathrm{~A}$ ). In the dinoflagellate mixtures, 3 probes (Ostreopsis_sp_ITS, Vulcanodinium_ITS_4 and Alex28S) presented less specificity by showing weak FS in the 4 mixtures. However, the absence of FS from the other Ostreopsis and Vulcanodinum oligonucleotide probes excluded their presence in the mixtures.

\subsection{Sensitivity of the Phytochip}

To test the Phytochip hybridization process and efficiency on a natural matrix, natural seawater was spiked with $A$. minutum and $P$. delicatissima cells. A prior inspection of the natural seawater under the light microscope revealed the presence of a few Pseudo-nitzschia cells from the seriata complex. On the phytochip, A. minutum was detected in all samples 
with the $28 \mathrm{~S}$ rDNA probes as revealed by high and specific FS for both the genus and species probes. The detection limit for Alexandrium minutum is lower than 50 cells because only 50 cells were enough to give a strong FS, for the Amin2-1 probe. The generic Alex28S probe reached directly saturation with the range of cells we tested (Fig. 2A). A positive FS for PSN_28S is observed indicating the presence of Pseudo-nitzchia cells in natural sampled sea water. This result confirmed the microscopic observations. However the identification of Pseudo-nitzschia species failed probably because of their too low concentration. For samples spiked with $P$. delicatissima culture, FS for clade and species probes were also found specific and allowed to detect 500 P. delicatissima cells (Fig. 2B).

\subsection{Detection in Environmental Samples}

The phytochip was used to identify Pseudo-nitzschia species in natural samples from the Bay of Concarneau. A good agreement was observed between the molecular methods (i.e microarray and clone libraries) and light microscopy observations (Fig. 3, Table 4 and S3). Nevertheless, a few disparities were observed between microarray and clone libraries results. In a few cases we obtained a positive microarray signal and their lack of the corresponding sequences in the libraries. Even if the coverage of the library is high, it is not maximal; the coverage ranges from 81.5 to $92.7 \%$. The presence of target species could thus be missed in the library because the number of clones sequenced was too low.

Using the Pseudo-nitzchia genus primers on environmental samples, only 9 out of 178 reliable sequences did not belong to Pseudo-nitzschia species but to other diatoms: 8 were affiliated to the Cylindrotheca genus and 1 sequence showed $89 \%$ identity with a Minutocellus sp. species. Thus, the primers and probes developed for the Phytochip seemed perfectly adequate to enrich and clearly detect Pseudo-nitzschia species in environmental 
samples. The microarray hybridization showed that the delicatissima complex dominated the Pseudo-nitzschia assemblage with a striking dominance of Pseudo-nitzschia species from the cuspidata/pseudodelicatissima complex which bloomed at sampling time-point BC21 (Fig. 3). Three species from the delicatissima complex were detected in these samples. $P$. fraudulenta and $P$. pungens were the most dominant species from the seriata complex and were detected in 6 and 3 samples, respectively (Table S3). P. australis was also detected in low numbers in $\mathrm{BC}$, whereas it was not identified in the clone libraries (Fig. 3). It is also interesting to notice that oligonucleotide probes from two species, $P$. dolorosa and $P$. subpacifica which were not validated because of the absence of monoclonal cultures from these species, presented a clearly positive FS in this sample and were also detected in the BC6 and $\mathrm{BC} 26$ gene libraries respectively (Table 4 and S3). Oligonucleotide probes of species from the seriata complex showed higher sensitivity; especially because of the high FS of the P. fraudulenta and P. pungens probes.

\section{Discussion}

Future diagnostic methods will rely on approaches that allow the immediate screening of multiple targets. These methods should be able to be performed quickly and with high specificity, but at the same time with minimal effort and materials to reduce costs. With this perspective in mind, we have developed the Phytochip for the identification of HAB species and monitoring of phytoplankton communities. The detection of phytoplankton species is achieved after the direct hybridization of labeled PCR products, which allows the protocol to remain simple and rapid. By using DNA as a target rather than RNA, it is possible to overcome some practical constraints: DNA is much more stable and it can be extracted easily from fixed samples. Even if DNA microarrays require an additional step for targeting rDNA 
genes (amplification and labeling), this step allows gaining sensitivity and specificity. For design purposes, we developed probes according to their thermodynamics and specificity regardless of the secondary structures they can adopt. The initial PCR amplification of target DNA has a major effect on microarray performance (Janse et al., 2012; Scheler et al., 2014). Using fluorochrome labeled primers, the PCR allows sample amplification and labeling in a single step. Furthermore it leads to a labeling efficiency that is theoretically similar for all oligo-pairs, making results easier to compare, which is in contrast to a post-PCR DNA labeling step where the incorporation of the fluorescence may vary (Russell et al., 2009). The asymmetric PCR performed with labeled primers also presents some other benefits. It increases the yield of target ssDNA and thus general fluorescence, and prevents hybridization competition between the target probe and the complementary strand (Szilvási et al., 2005). Moreover, the current asymmetric PCR could successfully co-amplify DNA from up to 7 target species or DNA from field samples without losing individual PCR products. The optimized assay protocol described in this paper allows identification of specific taxa within a single working day. With the microarray format chosen, eight samples can be analyzed in parallel on a single slide, allowing relatively high throughput and further automation. Even if the phytochip is not a quantitative assay, it can save time and reduce the cost of monitoring by screening and selecting only samples containing toxic target microalgae for additional analysis at the single species level to quantify them by microscope count or a specific Q-PCR. If the cell concentration exceeds the sanitary alert thresholds defined for each microalgae, biotoxin analysis will be performed in shellfish. In France, the official control system is based on both phytoplankton monitoring (Utermöhl) and analysis of marine biotoxins in shellfish. Recent reviews outline the requirement of most legislative systems to monitor for toxic phytoplankton species in shellfish production areas (de Grasse and Martinez-Diaz, 2012; 
Hess, 2012; Suzuki and Watanabe, 2012). Hence, our microarray, which has a high specificity and allows for simultaneously testing of several microalgae in parallel, could be used as part of an optimized early warning system.

Nonetheless, we observed a discrepancy between the number of in silico designed "potentially functional oligonucleotide probes" and the actual number of validated probes (in terms of specificity and FS). It had already been shown from bioinformatics computations that most probes do not perform as expected suggesting that the dynamics and processes of hybridization are not yet fully understood (Kochzius et al., 2010; Chen et al., 2009). In our experimental conditions, several probes did not display any FS, whereas others presented cross-hybridization because of lack of in situ specificity. The performance of probes can thus be unpredictable, especially when environmental samples containing numerous unknown organisms are analyzed (Peytavi et al., 2005). Therefore, to try to avoid these complications, we opted for a hierarchical design and developed several probes per species (Metfies and Medlin, 2008), on different positions along the rRNA operon. Thus, a set of probes was used instead of a single one to discriminate the species. The 81 functional probes we designed were tested for their specificity in simplex and multiplex experiments with 32 different phytoplankton species and various strains when possible. Regarding the microalgae tested in this study, we also found a large difference in term of specificity between probes designed from18S and ITS rDNA. Most of the $18 \mathrm{~S}$ rDNA probes showed a great deal of crosshybridization and thus a lack of discrimination. Similar results had been obtained with Barra et al. (2013) with 49 genus- and species-specific probes designed against the nuclear SSU and LSU rRNA for 19 Pseudo-nitzschia species where only three of them showed specificity. Thus the $18 \mathrm{~S}$ rDNA is apparently too conserved between the species and these probes were discarded from our Phytochip for the Pseudo-nitzschia identification. Most of the probes 
designed from the nuclear encoded ITS regions showed high specificity and FS, confirming that the ITS1-5.8S-ITS2 region offers a better, if not, the best resolution to discriminate HAB species. The ITS1 region had already been proven to be useful in differentiating Pseudonitzschia species in ARISA, quantitative PCR or microarrays (Hubbard et al., 2008; Andree et al., 2011; Smith et al., 2012). The ITS2 with its secondary structure had been found to be useful for taxonomic assignment at various levels (Coleman, 2003), especially the 5.8S-ITS2 region has been proposed as a successful DNA-barcoding region for diatoms (Moniz and Kaczmarska, 2010). However, given the high level of polymorphism in this region, designing probes for higher taxonomic levels (above genera) was more complicated. Higher taxonomic level probes should display roughly the same level of FS among and between the different genera avoiding bias towards some species. We failed to design higher taxonomic oligonucleotide probes from this region; they showed either no FS or irregular FS patterns. As they did not improve identification, they were discarded. Nevertheless, the specificity of molecular probes should be continuously re-evaluated because it is strongly dependent on the amount and the quality of sequences in the ribosomal data bases and accurate assignment at the time of the probe design (Wollschlager et al., 2014). The phytochip design offers a good possibility to introduce and set up new probes quickly and easily. In this study as in others, the absolute FS intensities were heterogeneous, which appeared to be a common feature in DNA microarray hybridization experiments (Rønning et al., 2005; Warsen et al., 2004; Kochzius et al., 2010; Peplies et al., 2003). Considering the principles of DNA duplex stability, FS intensities should be primarily connected to the nucleotide sequence of a probe. Peplies et al. (2003) have highlighted that the FS of a mismatched target for particular probes can be significantly higher than the perfect matched signals of other probes. Similar results were obtained in simplex assays using DNA from cultures. The FS of $P$. australis DNA with 
the probes PSN_seriataGrp_f4 and PSN_seriataGrp_f10 (originally designed for P. seriata) were higher than for P. seriata DNA with the seriata "specific" PSN_seriata_ITS_8 probe. However these two species can be considered as sister species (Lundholm et al., 2002) and are known to be difficult to distinguish on a molecular basis (Hubbard et al., 2008). The Position Of Label (POL) effect of the hybridization probe sequence may also explain some variations in fluorescence intensities (Zhang et al., 2005). Previous studies had already reported a decrease in the hybridization signal intensity as the distance between the binding site and the fluorescent label in the DNA-probe duplex increases (Kochzius et al., 2010). Looking at the Pseudo-nitzschia species for which we had various functional probes targeting the same marker, a significant POL effect was also observed; oligonucleotide probes binding with the sequence part with the shortest distance from the fluorescent label presented the highest FS (Fig. S1).

With our Phytovhip, we can respectively detect 50 and 500 cells of Alexandrium minutum and Pseudonitzschia delicatissima. This detection limit depends on several factors linked to the microarray assay procedure, but mostly on the target species DNAs. For monitoring purposes, it is crucial to assess the sensitivity for each target species to be sure that the detection limit is lower than the sanitary threshold. The sensitivity of a DNA microarray is higher than those obtained using RNA microarrays (Taylor et al., 2014). These authors recently calibrated the microarray signal to the RNA content and cell concentration for several Alexandrium species. The detection limit was found to be comprised between 700 and 7000 cells depending on the Alexandrium species. The detection limit for the Phytochip is in agreement with those obtained for other DNA microarrays (Galluzzi et al., 2011). Using a RNA microarray, Barra et al. (2013) and Medlin and Kegel (2014) found a detection threshold ranging between 1200 to 50000 cells for Pseudo-nitzschia spp, 
Even if a probe may seem promising from a bioinformatics perspective, cross hybridization can occur with closely related species. Considering that probe behavior cannot be predicted and in order to validate our Phytochip, probes were intensively tested with hybridization experiments run in simplex and multiplex to assess their application in species identification with several species, especially with Pseudo-nitzschia species. It is crucial to test closely-related species belonging to the same genus. For example, the two probes PSN_seriataGrp_f10 and PSN_seriataGrp_f4 first designed for P. seriata showed strong FS with the most closely related $P$. australis species in simplex; for this reason they were then considered to target both species (the P. seriata/ P. australis clade). However, it is worth to note the fluorescence decrease when these species was analyzed in multiplex. Designing a hierarchical set of probes proved absolutely essential; it limits false-positives (increase of specificity) and strengthens detection (increase of sensitivity).

The Phytochip was applied to field samples from the French Brittany region. A good congruence was observed between the Phytochip, microscopy and clone library results at the complex level (delicatissima/seriata) (Fig. 3). In contrast to the microscopy method, the Phytochip also gives information about the species level and presents the highest sensitivity. A larger diversity of Pseudo-nitzschia was estimated with the phytochip than with the clone libraries. Our clone libraries probably underestimated the occurrence of taxons, because the coverage ranged only between 81.5 and 92.7 percent. The number of sequenced clones was probably insufficient to detect all Pseudo-nitzschia species in the environmental samples. The microarray signal obtained for the taxa that were not detected in the libraries was also low, probably because of the low abundances of the species underlying once more the sensitivity of our phytochip. It is unlikely that this detection was because of nonspecific binding of 
probes to non-target species because the probes were previously validated using natural seawater spiked with various amount of cells of these specific species.

In the delicatissima group, we observed that P. cuspidata/pseudodelicatissima was present in all samples and represented the dominant species in the observation series on this site. $P$. delicatissima and $P$. arenysensis were also detected in most of the samples but in lower quantities. Moreover, probes of two untested species P. dolorosa and P. subpacifica showed weak FS in BC6 and BC26 samples, respectively. We know that P. subpacifica appeared on the French coast for the first time in 2004 and has since been observed on the South West coast of Brittany (Nezan et al., 2007). One sequence of this species was also retrieved from our clone libraries in one of these same samples, suggesting that this species may indeed be present at very low concentrations in natural sea water. Diversity was maximal in BC26 (Mid-July). Such type of distribution has already been reported in summer, the species of the seriata-group blooming after the delicatissima-group (Fehling et al., 2006; Downes-Tettmar et al., 2013).

\section{Conclusion}

The Phytochip enables accurate multiplex identification of toxic phytoplankton even at low concentrations. Multiple species can be detected even if present at different ratios, which is often the case during bloom periods. Comparing to the standard method i.e., light microscopic observation, the strengths of the microarray technique is its ease of use, independence from the trained observer and rapidity. Moreover, it allows higher taxonomic resolution, successfully demonstrated by our diversity study of Pseudo-nitzschia species. For a routine monitoring program, the Phytochip could thus represent a useful tool as an early 
warning system when used in tandem with microscopic cell counts for screening a large data set targeted on toxic or associated taxa.

\section{Acknowledgements}

The work was funded by the COMANCHE program (ANR-2010-STRA-010). Charlotte Noyer was supported by an Ifremer postdoctoral fellowship. We sincerely acknowledge the assistance of several colleagues in sharing biological materials for the Phytochip assessment (Table S1). We are very grateful to Raffaele Siano (Ifremer) and Valerian Leroy (Ifremer) for field sampling and Pseudo-nitzchia identification. We would like to thank Dr. Marcel Koken (CNRS) and Emlyn Williams for critically reading the manuscript and correcting the English.

\section{References:}

Altschul, S.F., Gish, W., Miller, W., Myers, E.W., Lipman, D.J., 1990. Basic local alignment search tool. J. Mol. Biol. 215, 403-410

Andersen, R.A., 2005. Algal Culturing Techniques. Elsevier, p. 565

Andree, K.B., Fernandez-Tejedor, M., Elandaloussi, L.M., Quijano-Scheggia, S., Sampedro, N., Garces, E., Camp, J., Diogene, J., 2011. Quantitative PCR coupled with melt curve analysis for detection of selected Pseudo-nitzschia spp. (Bacillariophyceae) from the Northwestern Mediterranean Sea. Appl. Environ. Microbiol. 77, 1651-1659.

Barra, L., Ruggiero, M.V., Sarno, D., Montresor, M., Kooistra, W.H.C.F., 2013. Strength and weakness of microarray approaches to detect Pseudo-nitzschia species in the field. Environ. Sci. Pollut. Res. 20, 6705-6718. 
Brand, L.E., Campbell, L., Bresnan, E., 2012. Karenia: The biology and ecology of a toxic genus. Harmful Algae 14, 156-178.

Chen, W., Seifert, K., Lévesque, C., 2009. A high density COX1 barcode oligonucleotide array for identification and detection of species of Penicillium subgenus Penicillium. Mol. Ecol. Resour. 9, 114-129.

Coleman, A.W., 2003. ITS2 is a double-edged tool for eukaryote evolutionary comparisons. Trends Genet. 19, 370-375.

Cooper, E.D., Bentlage, B., Gibbons, T.R., Bachvaroff, T.R., Delwiche, C.F., 2014. Metatranscriptome profiling of a harmful algal bloom. Harmful algae 37, 75-83.

De Grasse, S.L., Martinez-Diaz, K., 2012. Biotoxin control programmes in North, Central, and South American countries. In: Cabado, A.G., Vieites J.M. (Eds.), New trends in marine and freshwater toxins: food safety concerns. Nova Science Publishers, Inc. Chapter 11.

Delaney, J.A., Ulrich, R.M., Paul, J.H., 2011 Detection of the toxic marine diatom Pseudonitzschia multiseries using the RuBisCO small subunit (rbcS) gene in two real-time RNA amplification formats. Harmful algae 11, 54-64.

Downes-Tettmar, N., Rowland, S., Widdicombe, C., Woodward, M., Llewellyn, C., 2013. Seasonal variation in Pseudo-nitzschia spp. and domoïc acid in the Western English Channel. Cont. Shelf Res. 53, 40-49.

Ebenezer, V., Medlin, L.K., Ki, J.S., 2011. Molecular detection, quantification, and diversity evaluation of microalgae. Mar. Biotechnol. 14, 129-142.

Edvardsen, B., Dittami, S.M., Groben, R., Brubak, S., Escalera, L., Rodriguez, F., Reguera, B., Chen, J.X., Medlin, L.K., 2013. Molecular probes and microarrays for the detection 
of toxic algae in the genera Dinophysis and Phalacroma (Dinophyta). Environ. Sci. Pollut. Res. 20, 6733-6750.

Fehling, J., Davidson, K., Bolch, C., Tett P., 2006. Seasonality of Pseudo-nitzschia spp. (Bacillariophyceae) in western Scottish waters. Mar. Ecol. Prog. Ser. 323, 91-105.

Franke-Whittle, I.H., Goberna, M., Pfister, V.; Insam, H., 2009. Design and development of the ANAEROCHIP microarray for investigation of methanogenic communities. J. Microbiol. Methods 79, 279-288.

Galluzzi, L., Cegna, A., Casabianca, S., Penna, A., Saunders, N., Magnani, M., 2011. Development of an oligonucleotide microarray for the detection and monitoring of marine dinoflagellates. J. Microbiol. Methods 84, 234-242.

Gentry, T.J., Wickham, G.S., Schadt, C.W., He, Z., Zhou, J., 2006. Microarray applications in microbial ecology research. Microb. Ecol. 52, 159-175.

Gescher, C., Metfies, K., Medlin, L.K., 2008a. The ALEX CHIP - Development of a DNA chip for identification and monitoring of Alexandrium. Harmful Algae 7, 485-494.

Gescher, C., Metfies, K., Frickenhaus, S., Knefelkamp, B., Wiltshire, K.H., Medlin, L.K., 2008b. Feasibility of assessing the community composition of prasinophytes at the Helgoland roads sampling site with a DNA microarray. Appl. Environ. Microbiol. 74(17), 5305-5316

Hall, T.A., 1999. BioEdit: a user-friendly biological sequence alignment editor and analysis program for Windows 95/98/NT. Nucleic Acids Symposium 41, 95-98.

Hariganeya, N., Tanimoto, Y., Yamaguchi, H., Nishimura, T., Tawong, W., Sakanari, H., Yoshimatsu, T., Sato, S., Preston, C.M., Adachi, M., 2013. Quantitative PCR method for enumeration of cells of cryptic species of the toxic marine Dinoflagellate Ostreopsis spp. in coastal waters of Japan. PLoS One 8, e57627. 
He, Z., Zhou, J., 2008. Empirical evaluation of a new method for calculating signal-to-noise ratio for microarray data analysis. Appl. Environ. Microbiol. 74(10): 2957.

Hess, P. (2012) Phytoplankton and biotoxin monitoring programmes for the safe exploitation of shellfish in Europe. In: Cabado, A.G., Vieites J.M. (Eds.), New trends in marine and freshwater toxins: food safety concerns. Nova Science Publishers, Inc. Chapter 12.

Hubbard, K.A., Rocap, G., Armbrust, E.V., 2008. Inter- and intraspecific community structure within the diatom genus Pseudo-nitzschia (Bacillariophyceae). J. Phycol. 44, 637-649.

Janse, I., Bok, J.M., Hamidjaja, R.A., Hodemaekers, H.M., Rotterdam, B.J van., 2012. Development and comparison of two assay formats for parallel detection of four biothreat pathogens by using suspension microarrays. PLoS One 7:e31958.

Kaczmarska, I., Martin, J.L., Ehrman, J.M., LeGresley, M.M., 2007. Pseudo-nitzschia species population dynamics in the Quoddy Region, Bay of Fundy. Harmful Algae 6, 861-874.

Kalendar, R., Lee, D., Schulman, A.H., 2011. Java web tools for PCR, in silico PCR, and oligonucleotide assembly and analysis. Genomics 98, 137-144.

Karlson, B., Cusack, C., Bresnan, E., 2010. Microscopic and molecular methods for quantitative phytoplankton analysis. Intergovernmental Oceanographic Commission of UNESCO, Paris, (109 pp.).

Kavanagh, S., Brennan, C., O'Connor, L., Moran, S., Salas, R., Lyons, J., Silke, J., Maher, M., 2010. Real-time PCR detection of Dinophysis species in Irish coastal waters. Mar. Biotechnol. 12, 534-542.

Kochzius, M., Seidel, C., Antoniou, A., Botla, S.K., Campo, D., Cariani, A., Vazquez, E.G., Hauschild, J., Hervet, C., Hjorleifsdottir, S., Hreggvidsson, G., Kappel, K., Landi, M., Magoulas, A., Marteinsson, V., Nolte, M., Planes, S., Tinti, F., Turan, C., Venugopal, 
M.N., Weber, H., Blohm, D., 2010. Identifying fishes through DNA barcodes and microarrays. PLoS One 5:e12620.

Le Berre, V., Trevisiol, E., Dagkessamanskaia, A., Sokol, S., Caminade, A.M., Majoral, J.P., Meunier, B., Francois, J., 2003. Dendrimeric coating of glass slides for sensitive DNA microarrays analysis. Nucleic Acids Res. 31:e88.

Lelong, A., Hégaret, H., Soudant, P., Bates, S.S., 2012. Pseudo-nitzschia (Bacillariophyceae) species, domoic acid and amnesic shellfish poisoning: revisiting previous paradigms. Phycologia 51, 168-216.

Lenaers, G., Maroteaux, L., Michot, B., Herzog, M., 1989. Dinoflagellates in evolution. A molecular phylogenetic analysis of large subunit ribosomal RNA. J. Mol. Evol. 29, 4051.

Letowski, J., Brousseau, R., Masson, L., 2004. Designing better probes: effect of probe size, mismatch position and number on hybridization in DNA oligonucleotide microarrays. J. Microbiol. Methods 57, 269-278.

Ludwig, W., Strunk, O., Westram, R., Richter, L., Meier, H., Yadhukumar, Buchner, A., Lai, T., Steppi, S., Jobb, G., Forster, W., Brettske, I., Gerber, S., Ginhart,A.W., Gross, O., Grumann, S., Hermann, S., Jost, R., Konig, A., Liss, T., Lussmann, R., May, M., Nonhoff, B., Reichel, B., Strehlow, R., Stamatakis, A., Stuckmann, N., Vilbig, A., Lenke, M., Ludwig, T., Bode, A., Schleifer, K.H., 2004. ARB: a software environment for sequence data. Nucleic Acids Res. 32, 1363-1371.

Lundholm, N., Hasle, G.R., Fryxell, G.A., Hargraves, P.E., 2002. Morphology, phylogeny and taxonomy of species within the Pseudo-nitzschia americana complex (Bacillariophyceae) with descriptions of two new species, Pseudo-nitzschia brasiliana and Pseudo-nitzschia linea. Phycologia, 41, 480-497. 
McCoy, G.R., Touzet, N., Fleming, G.T., Raine, R., 2013. An evaluation of the applicability of microarrays for monitoring toxic algae in Irish coastal waters. Environ. Sci. Pollut. Res. 20, 6751-6764

McDonald, S.M., Sarno, D., Zingone, A., 2007. Identifying Pseudo-nitzschia species in natural samples using genus-specific PCR primers and clone libraries. Harmful Algae 6, 849-860.

Medlin, L.K., Kegel, J.U. 2014. Validation of the detection of Pseudo-nitzschia spp. using specific RNA probes tested in a microarray format: Calibration of signal based on variability of RNA content with environmental conditions. Harmful Algae 37, 183-193.

Metfies, K., Medlin, L.K., 2007. Refining cryptophyte identification with DNA-microarrays. J. Plankton Res. 29, 1071-1075.

Metfies, K, Medlin, L.K., 2008. Feasibility of transferring fluorescent in situ hybridization probes to an $18 \mathrm{~S}$ rRNA gene phylochip and mapping of signal intensities. Appl. Environ. Microbiol. 74, 2814-2821.

Metfies, K., Gescher, C., Frickenhaus, S., Niestroy, R., Wichels, A., Gerdts, G., Knefelkamp, B., Wiltshire, K., Medlin, L., 2010. Contribution of the class cryptophyceae to phytoplankton structure in the German bight. J. Phycol. 46(6), 1152-1160.

Moniz, M.B.J., Kaczmarska, I., 2010. Barcoding of Diatoms: Nuclear Encoded ITS Revisited. Protist 161, 7-34.

Murray, M.G., Thompson, W.F., 1980. Rapid isolation of high molecular weight plant DNA. Nucleic Acids Res. 8, 4321-4326.

Nezan, E., Chomerat, N., Crassous, M.P., Antoine, E., 2007. Identification of Pseudonitzschia multistriata and P. subpacifica from French waters. Were they part of the cryptic flora? Harmful Algae News 35, 5-6. 
Orr, R.J.S., Stuken, A., Rundberget, T., Eikrem, W., Jakobsen, K.S., 2011. Improved phylogenetic resolution of toxic and non-toxic Alexandrium strains using a concatenated rDNA approach. Harmful Algae 10, 676-688.

Penna, A., Galluzzi, L., 2013. The quantitative real-time PCR applications in the monitoring of marine harmful algal bloom (HAB) species. Environ. Sci. Pollut. Res. 20, 6851-6862.

Peplies, J., Glöckner, F.O., Amann, R., 2003. Optimization Strategies for DNA MicroarrayBased Detection of Bacteria with 16S rRNA-Targeting Oligonucleotide Probes. Appl. Environ. Microbiol. 69, 1397-1407.

Peytavi, R., Liu-Ying, T., Raymond, F.R., Boissinot, K., Bissonnette, L., Boissinot, M., Picard, F.J., Huletsky, A., Ouellette, M., Bergeron, M.G., 2005. Correlation between microarray DNA hybridization efficiency and the position of short capture probe on the target nucleic acid. Biotechniques. 39, 89-96.

Pruesse, E., Quast, C., Knittel, K., Fuchs, B.M., Ludwig, W.G., Peplies, J., Glockner, F.O., 2007. SILVA: a comprehensive online resource for quality checked and aligned ribosomal RNA sequence data compatible with ARB. Nucleic Acids Res. 35, 71887196.

Rønning, S.B., Rudi, K., Berdal, K.G., Holst-Jensen, A., 2005. Differentiation of important and closely related cereal plant species (Poaceae) in food by hybridization to an oligonucleotide array. J. Agric. Food Chem. 53, 8874-8880.

Russell, S., Meadows, L.A., Russell, R.R., 2009. Microarray technology in practice. Academic Press, USA. 464 pp

Scheler, O., Glynn, B., Kurg A., 2014. Nucleic acid detection technologies and marker molecules in bacterial diagnostics. Expert Rev. Mol. Diagn. 14(4), 489-500. 
Scholin, C., Miller, P., Buck, K., Chavez, F., Harris, P., Haydock, P., Howard, J., Cangelosi, G., 1997. Detection and quantification of Pseudo-nitzschia australis in cultured and natural populations using LSU rRNA-targeted probes. Limnol Oceanogr. 42, 12651272.

Scorzetti, G., Brand, L.E., Hitchcock, G.L., Rein, K.S., Sinigalliano, C.D., Fell, J.W., 2009. Multiple simultaneous detection of Harmful Algal Blooms (HABs) through a high throughput bead array technology, with potential use in phytoplankton community analysis. Harmful Algae 8, 196-211.

Smith, M.W., Maier, M.A., Suciu, D., Peterson, T.D., Bradstreet, T., Nakayama, J., Simon, H.M., 2012. High resolution microarray assay for rapid taxonomic assessment of Pseudo-nitzschia spp. (Bacillariophyceae) in the field. Harmful Algae 19, 169-180.

Smith, K.F., de Salas, M., Adamson, J., Rhodes, L.L., 2014. Rapid and accurate identification by Real-Time PCR of biotoxin-producing Dinoflagellates from the family Gymnodiniaceae; Marine drugs 12, 1361-1376.

Suzuki, T., Watanabe, R., 2012. Shellfish toxin monitoring system in Japan and some Asian countries. . In: Cabado, A.G., Vieites J.M. (Eds.), New trends in marine and freshwater toxins: food safety concerns. Nova Science Publishers, Inc. Chapter 10.

Szilvási, A., Andrikovics, H., Kalmár, L., Bors, A., Tordai, A., 2005. Asymmetric PCR increases efficiency of melting peak analysis on the LightCycler. Clinical Biochemistry. $38,727-730$.

Taylor, J.D., Kegel, J.U., Lewis, J.M., Medlin L.K., 2014. Validation of the detection of Alexandrium species using specific RNA probes tested in a microarray format: Calibration of signal using variability of RNA content with environmental conditions. Harmful algae 37, 17-27. 
Touzet, N., Keady, E., Raine, R., Maher, M., 2009. Evaluation of taxa-specific real-time PCR, whole-cell FISH and morphotaxonomy analyses for the detection and quantification of the toxic microalgae Alexandrium minutum (Dinophyceae), Global Clade ribotype. FEMS Microbiol. Ecol. 67, 329-341.

Trainer, V.L., Bates, S.S., Lundholm, N., Thessen, A.E., Cochlan, W.P., Adams, N.G., Trick, C.G., 2012. Pseudo-nitzschia physiological ecology, phylogeny, toxicity, monitoring and impacts on ecosystem health. Harmful Algae 14, 271-300.

Trevisiol, E., LeBerre-Anton, V., Leclaire „J., Pratviel G., Caminade, A.M., Majoral, J.P., Francois, J.M., Meunier, B., 2003. Dendrislides, dendrichips: a simple chemical functionalization of glass slides with phosphorus dendrimers as an effective means for the preparation of biochips. New J. Chem. 27, 1713-1719.

Trevisiol, E., Leclaire, J., Pratviel, G., Caminade, A.M., François, J.M., Majoral, J.P., Meunier B., 2009 Solid supports functionalized with phosphorus-containing dendrimers, process for preparing them and uses thereof, US patent 7, 517, 538.

Ulrich, R.M., Casper, E.T., Campbell, L., Richardson, B., Heil, C.A., Paul, J.H., 2010. Detection and quantification of Karenia mikimotoi using real-time nucleic acid sequence-based amplification with internal control RNA (IC-NASBA). Harmful Algae 9, 116-122.

Untergasser, A., Nijveen, H., Rao, X., Bisseling, T., Geurts, R., Leunissen, J.A.M., 2007. Primer3Plus, an enhanced web interface to Primer3. Nucleic Acids Res. 35, 71-74.

Warsen, A.E., Krug, M.J., LaFrentz, S., Stanek, D.R., Loge, F.J., Call, D.R., 2004. Simultaneous discrimination between 15 fish pathogens by using 16S Ribosomal DNA PCR and DNA microarrays. Appl. Environ. Microbiol. 70, 4216-4221. 
White, T.J., Bruns, T., Lee, S., Taylor, J.W., 1990. Amplification and direct sequencing of fungal ribosomal RNA genes for phylogenetics. In: Innis, M.A., Gelfand D.H., Sninsky, J.J., White, T.J., editors. PCR protocols: a guide to methods and applications. New York, N.Y: Academic Press, Inc.; pp. 315-322.

Wollschlager, J., Nicolaus, A., Wiltshire, K.H., Metfies K., 2014. Assessment of North Sea phytoplankton via molecular sensing: a method evaluation. J. Plankton Res. 36, 695708.

Ye, J., Coulouris, G., Zaretskaya, I., Cutcutache, I., Rozen, S., Madden , T.L., 2012. PrimerBLAST: a tool to design target-specific primers for polymerase chain reaction. BMC Bioinformatics, 13, 134.

Zhang, L., Hurek, T., Reinhold-Hurek, B., 2005. Position of the fluorescent label is a crucial factor determining signal intensity in microarray hybridizations. Nucleic Acids Res. 33(19): e166.

Zhang, F.Y., Shi, Y.H., Jiang, K.J., Song, W., Ma, C.Y., Xu, Z.L., Ma, L.B., 2014. Rapid detection and quantification of Prorocentrum minimum by loop-mediated isothermal amplification and real-time fluorescence quantitative PCR. J. Appl. Phycol. 26, 13791388. 


\section{Data Accessibility}

Sequences were deposited in GenBank under the Accession numbers KM245341 to KM245518.

\section{Author Contributions}

C.D., V.L.B designed research; C.N., C.D., A. A. and L.T performed research; C.N., C.D and V.L.B. analyzed data and wrote the paper. 


\section{Figure legends}

Fig. 1 Hierarchical key for the identification of Pseudo-nitzschia species on the Phytochip. For example, if $P$. delicatissima is present in the sample, it must have a positive signal with probes from the species ( $P$. delicatissima), its genus (Pseudo-nitzchia) and clade $(P$. delicatissima complex). If there is only a positive signal with the probe for the $P$. delicatissima species, this will be considered as a false positive.

Fig. 2 Seawater spiked with an increasing number of cells and tested on the phytochip (A) spiked with Alexandrium minutum cells. Please note that most of the Alexandrium sample signals were saturated as we have indicated by dashing of the bars; (B) spiked with Pseudonitzschia delicatissima cells.

Fig. 3 Evolution of the relative proportions of Pseudo-nitzschia from environmental samples collected in the Bay of Concarneau. (A) light microscopy; (B) clone libraries, (C) Phytochip. BC: Bay of Concarneau sample

\section{Table legends}

Table 1 Primers for labeled amplification

Table 2 Oligonucleotide probes for the hierarchical identification of HAB species.

Table 3 Detection of species in mixtures using the Phytochip. Genomic DNA was mixed in equal ratio consisting of (A) Pseudo-nitzschia species and (B) dinoflagellate species. 
Table 4 Characteristics and diversity of clone libraries obtained from environmental samples collected in the Bay of Concarneau 
Table 1 Primers for labeled amplification

\begin{tabular}{|c|c|c|c|c|c|c|}
\hline $\begin{array}{c}\text { Primer } \\
\text { name }\end{array}$ & Marker & Target & Direction & Sequence $\left(5^{\prime}-3^{\prime}\right)$ & $\mathrm{Ta}\left(\mathrm{C}^{\circ}\right)$ & References \\
\hline $82 \mathrm{~F}^{*}$ & $18 \mathrm{~S}(\mathrm{SSU})$ & Eukaryotes & Forward & GAAACTGCGAATGAATGGCTC & 48 & $\begin{array}{l}\text { Metfies and Medlin 2007, } \\
2008\end{array}$ \\
\hline $1528 \mathrm{R}$ & $18 \mathrm{~S}(\mathrm{SSU})$ & Eukaryotes & Reverse & TGATCCTTCTGCAGGTTCACCTAC & 48 & \\
\hline $\mathrm{D} 1 \mathrm{R}^{*}$ & $28 \mathrm{~S}$ (LSU) & Eukaryotes & Forward & ACCCGCTGAATTTAAGCATA & 55 & Lenaers et al., 1989 \\
\hline $\mathrm{D} 2 \mathrm{C}$ & $28 \mathrm{~S}(\mathrm{LSU})$ & Eukaryotes & Reverse & CCTTGGTCCGTGTTTCAAGA & 55 & \\
\hline ITS1* & ITS1-5,8S-ITS2 & Eukaryotes & Forward & TCCGTAGGTGAACCTGCGG & 48 & White et al., 1990 \\
\hline ITS4 & ITS1-5,8S-ITS2 & Eukaryotes & Reverse & TCCTCCGCTTATTGATATGC & 48 & \\
\hline PSN_F1* & ITS1-5,8S-ITS2 & Pseudo-nitzschia & Forward & GGATCATTACCACACCGATCC & 58 & designed for this study \\
\hline PSN_R1 & ITS1-5,8S-ITS2 & Pseudo-nitzschia & Reverse & ССTCTTGCTTGATCTGAGATCC & 58 & \\
\hline
\end{tabular}

* labeled Cy5. Ta: annealing temperature. 
Table 2 Oligonucleotide probes for the hierarchical identification of HABs species. Toxigenic species are marked by an asterisk.

\begin{tabular}{|c|c|c|c|c|c|}
\hline Genus & Clade & Species & Probe name & Marker & Sequence $\left(5^{\prime}-3^{\prime}\right)$ \\
\hline \multirow[t]{30}{*}{ Pseudo-ni } & chia & & PSN_28S & $28 \mathrm{~S}$ & GACATCAACTCTGACTGCGCTCTTCC \\
\hline & & & PSN_genus_hf20 & ITS & AGTGGGATCCACAGACACTCAGACAAG \\
\hline & & & PSN_genus_hf8 & ITS & TCCCGAAAGCGCAATGTGCGTTCAAAA \\
\hline & \multirow[t]{3}{*}{ delicatissima complex } & & PSN_delicatGrp_ITS_5 & ITS & AGAGGCAGTCAAGGCCAAAGCAACC \\
\hline & & delicatissima* & PSN delicat ITS 7 & ITS & GCCTACAGAATAGACCAGTGCTGAG \\
\hline & & arenysensis & PSN_arenys_ITS_26 & ITS & TGAAACGATGCCGAAGCAGAGGTCG \\
\hline & \multirow{4}{*}{\multicolumn{2}{|c|}{ cuspidata/pseudodelicatissima }} & PSN_cuspidata_ITS_27 & ITS & CGCTCCTGAATAGTAAGATCCAGGCAG \\
\hline & & & PSN_pseudo_cuspi_ITS_2 & ITS & ACAGTCAGTTCAGACCGTCAAAGCCA \\
\hline & & & PSN_pseudodelicat_ITS_20 & ITS & AGAGATAGACGAGAATGTCAGCACCGT \\
\hline & & & PSN_pseudodelicat_ITS_4 & ITS & AGTGAGAAATCACCAGTGCTGAGTGGG \\
\hline & \multirow[t]{20}{*}{ seriata/australis } & & PSN_seriataGrp_f10 & ITS & CGACAGCGACGGAGAGCTTTAAAAGCA \\
\hline & & & PSN_seriataGrp $\mathrm{f4}$ & ITS & GTTTGACGACAGCGACGGAGAGCTT \\
\hline & & seriata* & PSN_seriata_ITS 8 & ITS & CAACCAGCGACCGGCCTAAACCAG \\
\hline & & australis* & PSN_austr5-2m & ITS & GACAAGACAGGTTGAGGTCTCTAAATC \\
\hline & & & PSN_australis5M & ITS & ACAGGTTGAGGTCTCTAAATCTATGCAC \\
\hline & & americana & PSN_americana31m & ITS & CCTAGCTGGCACCGAGCCTGAAATC \\
\hline & & & PSN_americana_f10 & ITS & GAGACAGCGAAACGCAGTCAAAGCC \\
\hline & & & PSN_americana_ITS 8 & ITS & ACAAGAGTGCCAACGCCGTCTTTC \\
\hline & & calliantha* & PSN_calliantha_mannii_ITS_30 & ITS & TAGTACAGCAGTCAAGCTGCTGCCC \\
\hline & & & PSN_calliantha1-2 & ITS & GGACGACATAGTACAGCAGTCAAGCTG \\
\hline & & & PSN_calliantha3-1m & ITS & GAATTTAAGCAAAGACAGCAGCGGCTG \\
\hline & & & PSN_calliantha_ITS_19 & ITS & GCTACTGGAGCAGCAACCACCGTC \\
\hline & & fraudulenta* & PSN_fraudulenta1m & ITS & CCGAAGCCAGAGTGCCACGCAAATC \\
\hline & & & PSN_fraudulenta_f13 & ITS & GTTGCCGGACCACTGCACTTTAAGC \\
\hline & & & PSN_fraudulenta_ITS_41 & ITS & CTTAATGCCACTGGTGCGATGTCGC \\
\hline & & & PSN_fraudulenta_ITS_50 & ITS & AGGTTTTATGTACAGGGCGGCTCCTG \\
\hline & & galaxiae* $^{*}$ & PSN_galax_decip_ITS_15 & ITS & GTTTTTGTACAGGGCACACGGTGCT \\
\hline & & & PSN_galaxiae_ITS_6 & ITS & CTGCACCGCGATGAAGTTTGACGAC \\
\hline & & & PSN_galaxiae_ITS_1 & ITS & CCGTCCTTCGGACAAGCCAAGACTT \\
\hline & & multiseries* & PSN_multiseries6 & ITS & GCAAAGTATCAGTGCCAAGCCTCTGC \\
\hline
\end{tabular}




\begin{tabular}{|c|c|c|c|c|c|}
\hline & & & $\begin{array}{l}\text { PSN_multiseries_ITS_13 } \\
\text { PSN_multiseries_ITS_1 }\end{array}$ & $\begin{array}{l}\text { ITS } \\
\text { ITS }\end{array}$ & $\begin{array}{l}\text { CAAAACAACCAGCAGCCAGCACGAG } \\
\text { TCAAGCCTTCCACGTCTATGCACGT }\end{array}$ \\
\hline & & \multirow[t]{4}{*}{ multistriata* } & PSN_multistriata_f1 & ITS & GAGCCAGTTGCCACTGCAATCGAATC \\
\hline & & & PSN_multistriata_f9 & ITS & GCAGCGCCTAACCTCTGCATTTTTGC \\
\hline & & & PSN_multistriata3m & ITS & CACCTAGCAGAAAGTTGACGACACTGA \\
\hline & & & PSN_multistriata4m & ITS & TACTATGCAAGCTCGTCACCTAGCAGA \\
\hline & & \multirow[t]{3}{*}{ pungens* } & PSN_pungens_p1 & ITS & TCAGCGCTCCGAAACACTGCATCA \\
\hline & & & PSN_pungens1-5bm & ITS & CGTTGCAAGTTTAAGTTTGACGGCAGC \\
\hline & & & PSN_pungens_ITS_4 & ITS & CAGTGCCAGCAATAGAGTCGGTTTGGT \\
\hline \multirow{5}{*}{\multicolumn{2}{|c|}{ Azadinium }} & & Azadinium_ITS_1 & ITS & AGAACCCGACAGCAGGAATGAGGCT \\
\hline & & & Azadinium ITS 11 & ITS & GCTACTGGCATTAGAAGGTAGAGGCAC \\
\hline & & spinosum* & Azad_spinosum_ITS_47 & ITS & GAGCCACTCACAAGAAAGCATGGAAGC \\
\hline & & & Azad_spinosum_ITS_19 & ITS & GCACTTGGTTGTTGAGGCCACCTTC \\
\hline & & & Azad_spinosum_ITS_27 & ITS & AAGGTTCCCCACAAGCTCAATGCGT \\
\hline \multirow{4}{*}{\multicolumn{2}{|c|}{ Lingulodinium }} & polyedrum* & Lingu_polyedrum_ITS_22 & ITS & ACGGCATGCACATGCTGGAACAGAC \\
\hline & & & Lingu_polyedrum_ITS_30 & ITS & TACGGAAAAGCCTGCCTGCATGGTC \\
\hline & & & Lingu_polyedrum_ITS_47 & ITS & CCAGCAACCACGGCAGATTTTACGG \\
\hline & & & Lingu_polyedrum_ITS_52 & ITS & GGCGTATCCCAAAGGCACAGCAAAC \\
\hline \multirow{3}{*}{\multicolumn{2}{|c|}{ Ostreopsis }} & & Ostreopsis_sp_ITS & ITS & CAAGAAAAATGACTCACGGAATTCTGC \\
\hline & & ovata* & Ostreopsis_ovata_ITS & ITS & GGCCCAAGAACATGCCTACATTCAAG \\
\hline & & & Ostreopsis_ovata_ITS_2 & ITS & AAATGATGTCCTTAGGGGTGGCCCA \\
\hline \multirow{2}{*}{\multicolumn{2}{|c|}{ Vulcanodinium }} & rugosum* & Vulcano_ARB_ITS2_3 & ITS & CACAATGCTTCTCACAGTTCGCTGC \\
\hline & & & Vulcano_ITS_34 & ITS & CAGGCATGCTTCCAGGGATATCCCG \\
\hline \multirow{3}{*}{\multicolumn{2}{|c|}{ Prorocentrum }} & micans & Pmicans_ITS_2 & ITS & GGAAAGGAAGACAGTCCAATCCTGGCT \\
\hline & & & Pmicans_ITS_5 & ITS & GCAGGGACAGGAAAGGAAGACAGTCC \\
\hline & & & Kare28S ( ) & $28 \mathrm{~S}$ & CAGTATCGCATCCAGATCAAAACCT \\
\hline \multirow[t]{9}{*}{ Karenia } & \multicolumn{2}{|c|}{ brevis/mikimotoi/selliformis } & KareITS 49 & ITS & GGAAGACGGTCCAATATCACCCGGAC \\
\hline & \multicolumn{2}{|c|}{ brevis/mikimotoi/selliformis } & Kmiki brev ITS 38 & ITS & TGTCTCCAGCCAAGAGCACAACTCA \\
\hline & \multirow[t]{6}{*}{ brevis/mikimotoi } & & Kmiki brev ITS 47 & ITS & GAACTACCCGCGAGATTCTGCACAAG \\
\hline & & mikimotoi* & KmikiITS_23 & ITS & CATCAGGGGCAGGAAGAGCACCTTA \\
\hline & & & KmikiITS_6 & ITS & ACAGACACACACTGCTGTCAGTTGC \\
\hline & & & KmikitTS_8 & ITS & GGGCAGGAAGAGCACCTTAATGCAC \\
\hline & & & Kbrevis ITS 16 & ITS & TCACCCACGTCACCAGGAAGATTGA \\
\hline & & brevis* & Kbrevis_ITS_20 & ITS & AGCACGAAACCCATGCACTGTATGC \\
\hline & brevis/selliformis & & Kselli_brev_ITS 46 & ITS & GGCACAAATCACAGCAGGTGGTTCA \\
\hline
\end{tabular}




\begin{tabular}{|c|c|c|c|c|c|}
\hline & & \multirow[b]{2}{*}{ selliformis* } & & & \\
\hline & & & Kselli_ITS_29 & ITS & CAGGATCAGAGGCAAGGTTGTCAGTGC \\
\hline \multirow[t]{15}{*}{ Alexandrium } & & & Alex_SILVA & $18 \mathrm{~S}$ & CACACCACACAGTCAAGTGCAGTTGT \\
\hline & & & Alex28S & $28 \mathrm{~S}$ & ACCACCCACTTTGCATTCCAATGCC \\
\hline & & & Aminutum insuet SILV 5 & $18 \mathrm{~S}$ & TGACCACAACCCTTCCCAGAAGTCA \\
\hline & minutum/insuetum & & Aminutum SILV 9 & $18 \mathrm{~S}$ & CCCAGAAGTCAGGTTTGGATGCATG \\
\hline & & minutum* & Amin_ITS_8 & ITS & TGCAACAGCATTGACACACACAGCTCA \\
\hline & & & Amin_ITS_18 & ITS & CCCACCACAGCTCACAAAGTCATGC \\
\hline & & & Amin_ITS_23 & ITS & GCAGAACCTAAAGCCTAGGAACCCCAC \\
\hline & & & Amin2-1 & $28 \mathrm{~S}$ & TGCCAGCACTGATGTGTAAGGGCTT \\
\hline & & & Acat-tam_SILV 8 & $18 \mathrm{~S}$ & AACCAACGACCACAACCTTTCCCCC \\
\hline & tamarense/catenella & & A_tamarenseGrp_SILV_5 & $18 \mathrm{~S}$ & GGCGGACCAGCCATCCTCAGCA \\
\hline & & & A_tamarenseGrp_ITS & ITS & CTGTTAGCTCACGGAATTCTGC \\
\hline & & & Acatenella SILV 6 & $18 \mathrm{~S}$ & GGTTCTGCAACCAACGACCACAACC \\
\hline & & catenella* & Alexcat_15 & $28 \mathrm{~S}$ & GCACTACAATCTCACTGAGGAAATC \\
\hline & & & Alexcat 17 & $28 \mathrm{~S}$ & TTATTGCACTTGCAGCCAAAACCCA \\
\hline & & tamarense & Alex_tam 11 & $28 \mathrm{~S}$ & CATTACACCCACAGCCCAAAGCTCT \\
\hline
\end{tabular}


Table 3 Detection of species in mixtures using the Phytochip. Genomic DNA was mixed in equal ratio consisting of (A) Pseudo-nitzschia species and (B) dinoflagellates species.

\begin{tabular}{|c|c|c|c|c|c|c|}
\hline \multirow{2}{*}{$\begin{array}{l}\text { A) Composition: } \\
\text { Core species } \\
\text { Species not present } \\
\text { from the } \\
\text { composition }\end{array}$} & \multicolumn{6}{|c|}{$\begin{array}{c}\text { P. delicatissima; P. cuspidata/pseudodelicatissima; } P . \text { australis; P. seriata; } \\
\text { P. americana; P. fraudulenta; P. multiseries; P. pungens }\end{array}$} \\
\hline & P. americana $a^{(-)}$ & P. australis $^{(-)}$ & P. multiseries ${ }^{(-)}$ & P. pungens ${ }^{(-)}$ & P. delicatissima $a^{(-)}$ & $\begin{array}{l}P . \text { delicatissima }^{(-)} \\
P . \text { fraudulenta }^{(-)} \\
P . \text { arenysensis }^{(+)}\end{array}$ \\
\hline PSN_genus_hf20 & 65368 & 7555 & 35548 & 8163 & 46516 & 57739 \\
\hline PSN_genus_hf8 & 57683 & 5910 & 12867 & 6689 & 38935 & 24449 \\
\hline PSN_delicatGrp_ITS_5 & 26862 & 3124 & 10198 & 6093 & 42 & 6728 \\
\hline PSN_delicatissima_ITS_7 & 20397 & 1087 & 2960 & 2323 & - & - \\
\hline PSN_arenysensis_ITS_26 & - & - & - & - & - & 12872 \\
\hline PSN_cuspidata_ITS_27 & 6128 & 347 & 1356 & 1944 & 1042 & 1375 \\
\hline PSN_pseudodelicat_ITS_4 & 376 & & 3 & & & \\
\hline PSN_seriataGrp_f10 & 1436 & 658 & 881 & 2372 & 5261 & 4210 \\
\hline PSN_seriataGrp_f4 & 783 & 146 & 646 & 460 & 997 & 409 \\
\hline PSN_seriata_ITS_8 & 5465 & 119 & 1785 & 2219 & 2784 & 1630 \\
\hline PSN_australis5-2m & 2516 & - & 420 & 401 & 1402 & 985 \\
\hline PSN_americana $31 \mathrm{~m}$ & - & 33065 & 65415 & 65415 & 65408 & 65409 \\
\hline PSN_americana_f10 & - & 9768 & 7267 & 16014 & 11209 & 15212 \\
\hline PSN_fraudulentalm & 65315 & 54248 & 65409 & 65416 & 65408 & 12 \\
\hline PSN_fraudulenta_f13 & 11902 & 840 & 1579 & 2078 & 8570 & - \\
\hline PSN_fraudulenta_ITS_41 & 1090 & 2 & 516 & 149 & 366 & - \\
\hline PSN_fraudulenta_ITS_50 & 96 & & & 41 & & - \\
\hline PSN_multiseries6 & 20735 & 4256 & 65 & 16572 & 11161 & 9990 \\
\hline PSN_multiseries_ITS_13 & 185 & 42 & - & 63 & & 23 \\
\hline PSN_multiseries_ITS_1 & 361 & 1 & - & 190 & 21 & 17 \\
\hline PSN_pungens_p1 & 65346 & 65394 & 65413 & - & 65403 & 65381 \\
\hline PSN_pungens1-5bm & 65335 & 62717 & 65408 & - & 65403 & 65402 \\
\hline
\end{tabular}




\begin{tabular}{|c|c|c|c|c|}
\hline B) Species composition & $\begin{array}{l}\text { A. minutum, } \\
\text { A. catenella, } \\
\text { A. tamarense; } \\
\text { K. brevis, } \\
\text { K. selliformis }\end{array}$ & $\begin{array}{l}\text { A. minutum; } \\
\text { K. mikimotoi }\end{array}$ & $\begin{array}{l}\text { L. polyedrum; } \\
\text { K. mikimotoi, } \\
\text { K. brevis, } \\
\text { K. selliformis }\end{array}$ & $\begin{array}{l}\text { A. minutum; } \\
\text { K. mikimotoi, } \\
\text { K. selliformis }\end{array}$ \\
\hline PSN_genus_hf8 & 92 & & & 45 \\
\hline Lingu_polyedrum_ITS_22 & & & 2753 & \\
\hline Lingu_polyedrum_ITS_30 & & & 31046 & \\
\hline Lingu_polyedrum_ITS_47 & & & 42403 & \\
\hline Lingu_polyedrum_ITS_52 & & & 8685 & \\
\hline Ostreopsis_sp_ITS & 86 & 90 & 152 & 133 \\
\hline Vulcano_ARB_ITS2_3 & & & 130 & 85 \\
\hline Vulcanodinium_ITS_4 & 616 & 194 & 725 & 318 \\
\hline Kare28S & 158 & & & \\
\hline KareITS_49 & 31350 & 33173 & 55244 & 38705 \\
\hline Kmiki_brev_ITS_38 & 7058 & 65430 & 57271 & 58211 \\
\hline Kmiki_brev_ITS_47 & 29697 & 53993 & 65429 & 51455 \\
\hline KmikiITS_23 & & 652 & 1497 & 1220 \\
\hline KmikiITS_6 & & 888 & 1198 & 1283 \\
\hline KmikiITS_8 & 31 & 1172 & 2321 & 1891 \\
\hline Kbrevis_ITS_16 & 27215 & & 12751 & \\
\hline Kbrevis_ITS_20 & 2327 & & 430 & \\
\hline Kselli_brev_ITS_46 & 23926 & & 15474 & 4550 \\
\hline Kselli_ITS_29 & & & 97 & 159 \\
\hline Alex $28 \mathrm{~S}$ & 77 & 270 & 275 & 232 \\
\hline AminITS_8 & 1978 & 519 & & 745 \\
\hline AminITS_18 & 1886 & 954 & & 1462 \\
\hline AminITS_23 & 4894 & 2561 & & 3203 \\
\hline A_tamarenseGrp_ITS & 6451 & 77 & 88 & 92 \\
\hline Alexcat_17 & & & 6 & 14 \\
\hline
\end{tabular}


Table 4 Characteristics and diversity of clone libraries obtained from environmental samples collected in the Bay of Concarneau.

\begin{tabular}{|c|c|c|c|c|c|c|}
\hline Sample & Date & $\mathrm{N}$ & $\mathrm{S}$ & d & $\begin{array}{l}\text { Coverage } \\
(\%)\end{array}$ & Pseudo nitzschia species \\
\hline $\mathrm{BC} 2$ & $20 / 03 / 2012$ & 41 & 3 & 0.54 & 92.7 & $\begin{array}{l}\text { P. sp (cuspidata complex) } \\
\text { P. fraudulenta }\end{array}$ \\
\hline BC6 & $17 / 04 / 2012$ & 27 & 3 & 0.61 & 88.9 & $\begin{array}{l}\text { P. sp (cuspidata complex) } \\
\text { P. delicatissima. P. dolorosa }\end{array}$ \\
\hline $\mathrm{BC} 12$ & $14 / 05 / 2012$ & 37 & 3 & 0.55 & 91.9 & $\begin{array}{l}P . \text { sp (cuspidata complex) } \\
P . \text { fraudulenta. } P \text {. pungens }\end{array}$ \\
\hline $\mathrm{BC} 18$ & $12 / 06 / 2012$ & 24 & 4 & 0.94 & 83.3 & $\begin{array}{l}\text { P. sp (cuspidata complex) } \\
\text { P. fraudulenta. P. pungens }\end{array}$ \\
\hline $\mathrm{BC} 21$ & $26 / 06 / 2012$ & 22 & 2 & 0.32 & 90.9 & P. sp (cuspidata complex) \\
\hline $\mathrm{BC} 26$ & $12 / 07 / 2012$ & 27 & 5 & 1.21 & & $\begin{array}{l}\text { P. sp (cuspidata complex) } \\
\text { P. fraudulenta. P. pungens, } \\
\text { P. subpacifica }\end{array}$ \\
\hline
\end{tabular}

$\mathrm{N}$ : number of used sequences; S: number of OTUs; d: diversity estimated as Margalef species richness $(\mathrm{S}-1) / \log (\mathrm{N})$; coverage calculated as $1-\mathrm{S} / \mathrm{N}$ (McDonald et al. 2007). 


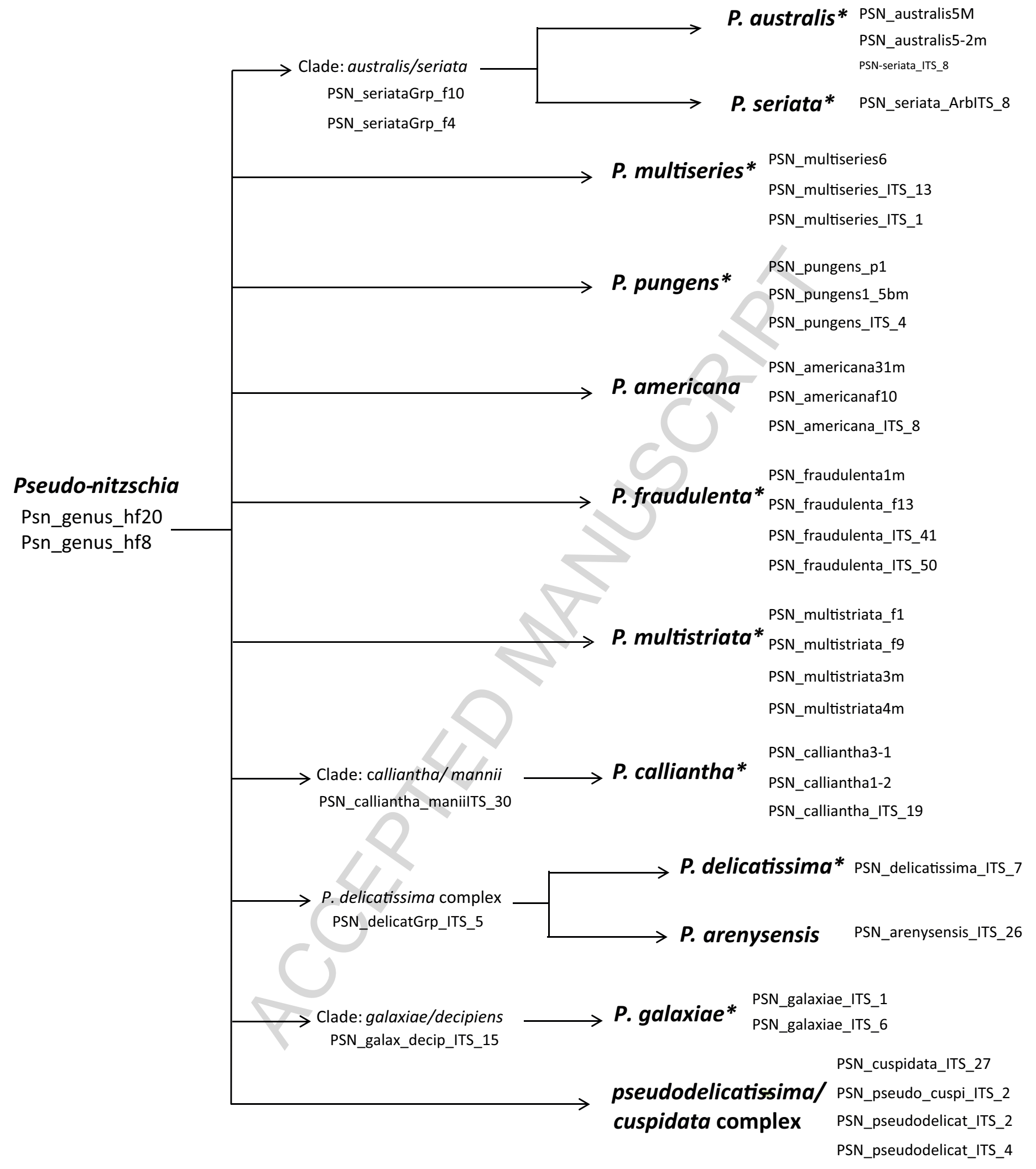

\section{Figure 1}


A

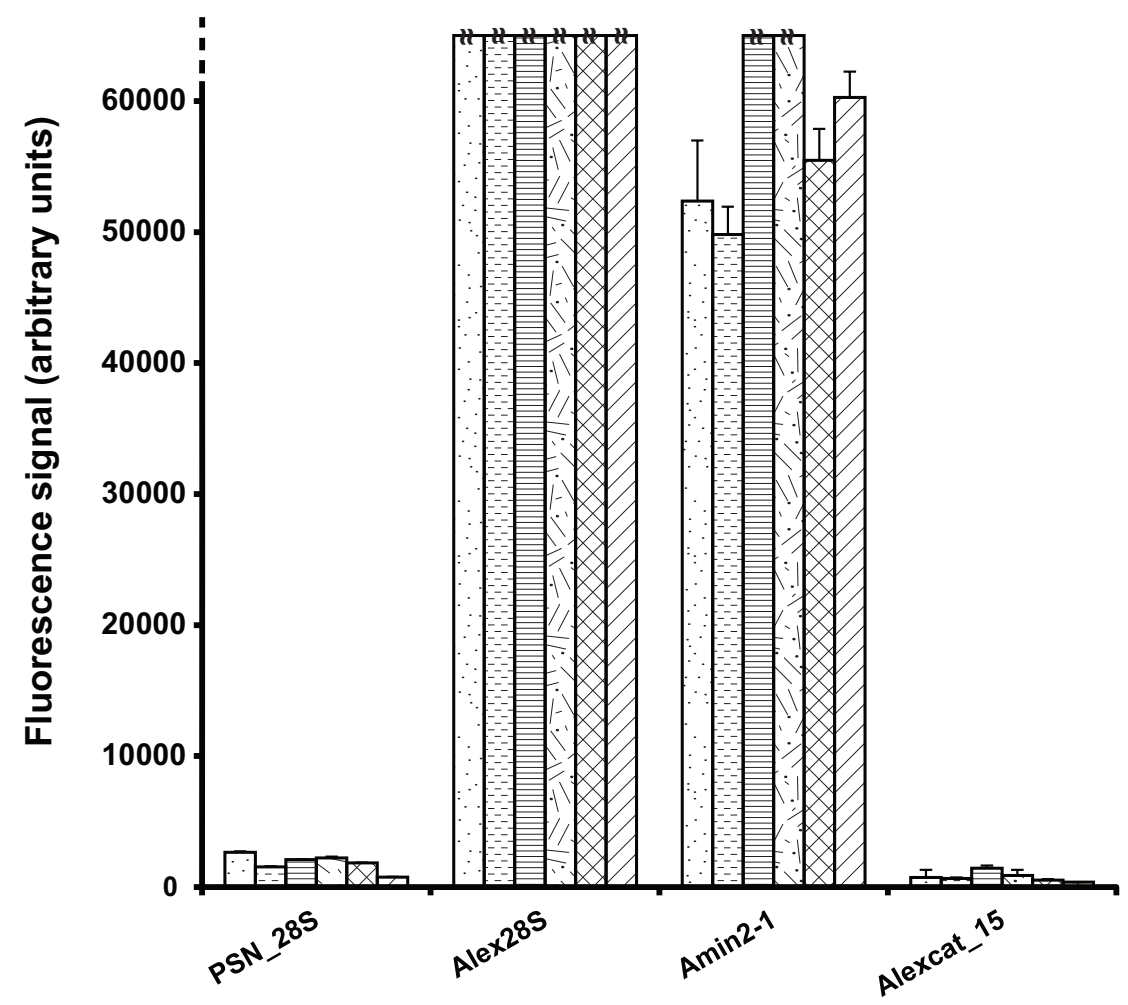

B

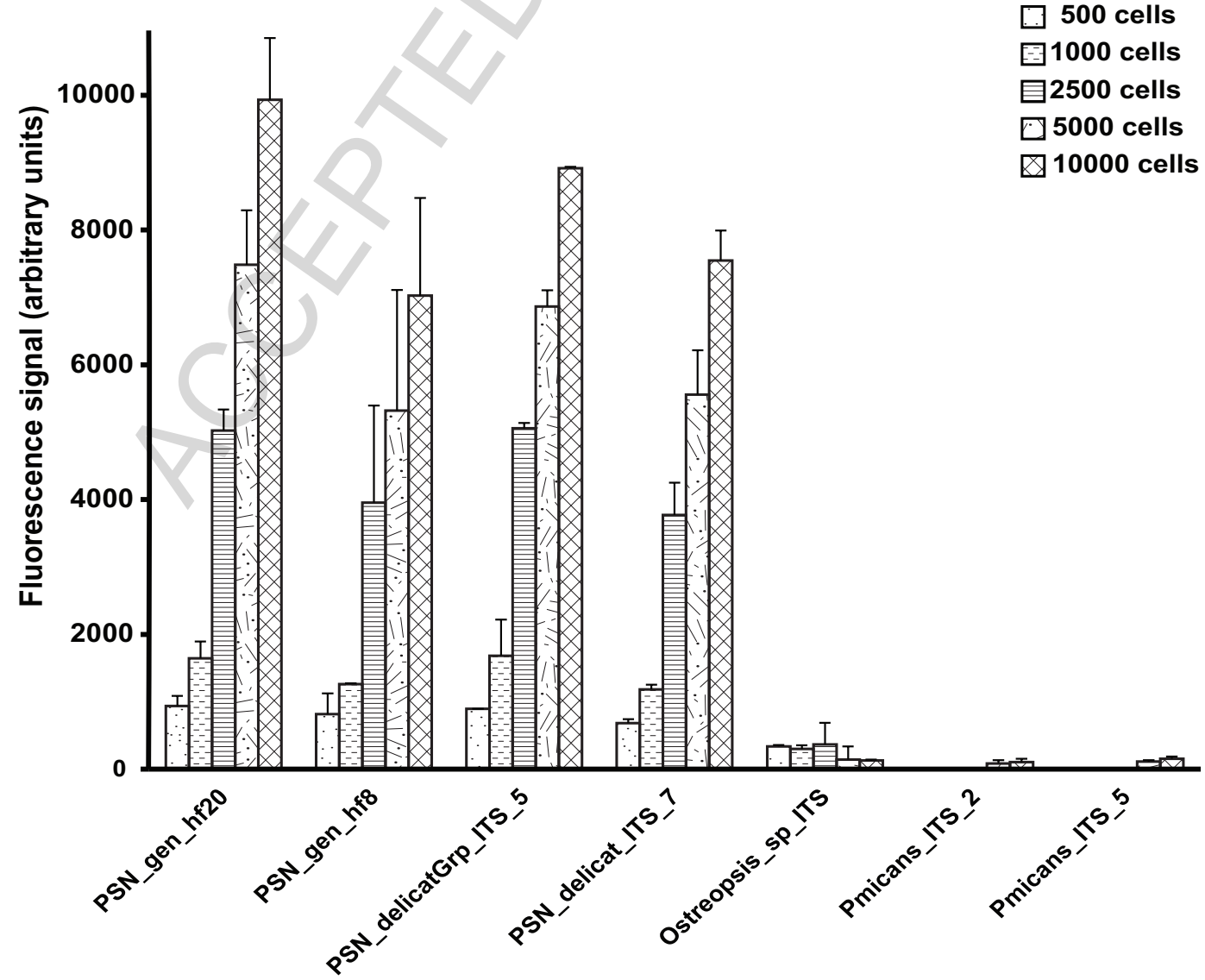

Pseudo-nitzschia delicatissima

$\square 500$ cells

000 cells

5000 cells

目 500 cells

$\square 1000$ cells

因2500 cells

$\square 5000$ cells

Figure 2 


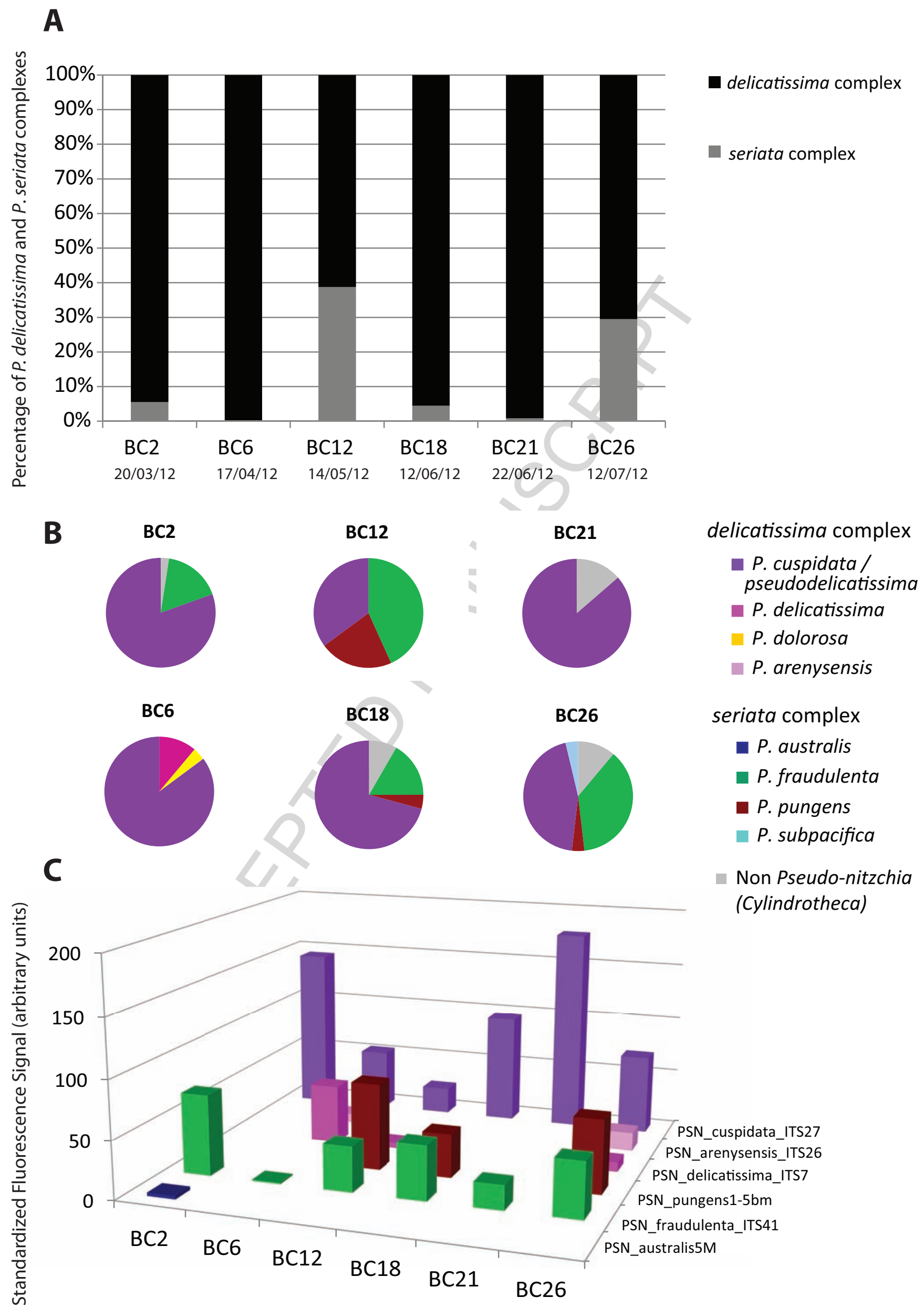

Figure 3 
Table S1: Microalgae used to test Phytochip specificity.

\begin{tabular}{|c|c|c|c|c|c|}
\hline Genus & Species & Strains & Collecting site & $\begin{array}{l}\text { Location } \\
\text { (culture or DNA bank) }\end{array}$ & Remarks \\
\hline Pseudo-nitzschia & australis & Cabourg (C6) & France, Cabourg & Caen University, France & J. Fauchot, M. Thorel \\
\hline Pseudo-nitzschia & australis & A1 & France, Boyard & Ifremer, France & \\
\hline Pseudo-nitzschia & australis & Kervel & France, Kervel & Ifremer, France & \\
\hline Pseudo-nitzschia & americana & Antifer & France, Antifer & Ifremer, France & \\
\hline Pseudo-nitzschia & americana & Cabourg & France, Cabourg & Ifremer, France & \\
\hline Pseudo-nitzschia & americana & Kervel & France, Kervel & Ifremer, France & \\
\hline Pseudo-nitzschia & fraudulenta & $\operatorname{Pn} 427$ & & Gent University, Belgium, & G. Casteleyn \\
\hline Pseudo-nitzschia & fraudulenta & LsM1 & France, Luc-sur-Mer & Caen University, France & J. Fauchot, M. Thorel \\
\hline Pseudo-nitzschia & fraudulenta & Cabourg (C4) & France, Cabourg & Caen University, France & J. Fauchot, M. Thorel \\
\hline Pseudo-nitzschia & fraudulenta & B2 & France, Baie de Seine & Ifremer, France & \\
\hline Pseudo-nitzschia & fraudulenta & CL192 & Canada, Deadman's Hbr & Ifremer, France & \\
\hline Pseudo-nitzschia & fraudulenta & CL194 & Canada, Bay of Fundy & Ifremer, France & \\
\hline Pseudo-nitzschia & fraudulenta & IFSA1 & France, Baie de Seine & Ifremer, France & \\
\hline Pseudo-nitzschia & seriata & CL160 & Canada, Tracadie bay & Ifremer, France & \\
\hline Pseudo-nitzschia & seriata & CL163 & Canada, Tracadie Bay & Ifremer, France & \\
\hline Pseudo-nitzschia & seriata & CL166 & Canada & Ifremer, France & \\
\hline Pseudo-nitzschia & seriata & CL167 & Canada, Rustico bay & Ifremer, France & \\
\hline Pseudo-nitzschia & seriata & CL168 & Canada, Rustico Bay & Ifremer, France & \\
\hline Pseudo-nitzschia & pungens & Pn567 & & Gent University, Belgium & G. Casteleyn \\
\hline Pseudo-nitzschia & pungens & CL200 & Canada, Miramichi bay & Ifremer, France & \\
\hline Pseudo-nitzschia & pungens & D10 & & Ifremer, France & \\
\hline Pseudo-nitzschia & pungens & PE6Kervel & France, Kervel & Ifremer, France & \\
\hline Pseudo-nitzschia & calliantha & D1 & France, Men Du & Ifremer, France & \\
\hline Pseudo-nitzschia & calliantha & D2 & France, Men Du & Ifremer, France & \\
\hline Pseudo-nitzschia & calliantha & D9 & France, Men Du & Ifremer, France & \\
\hline Pseudo-nitzschia & multiseries & CL174 & Canada, Cardigan Bay & Ifremer, France & \\
\hline Pseudo-nitzschia & multiseries & CL191 & Canada, Deadman's Hbr & Ifremer, France & \\
\hline Pseudo-nitzschia & multiseries & CL195 & Canada, Bay of fundy & Ifremer, France & \\
\hline Pseudo-nitzschia & multiseries & CL197 & Canada, Mirimachi Bay & Ifremer, France & \\
\hline Pseudo-nitzschia & multiseries & Pn556 & & Gent University, Belgium & G. Casteleyn \\
\hline
\end{tabular}




Pseudo-nitzschia
Pseudo-nitzschia
Pseudo-nitzschia
Pseudo-nitzschia
Pseudo-nitzschia
Pseudo-nitzschia
Pseudo-nitzschia
Pseudo-nitzschia
Pseudo-nitzschia
Pseudo-nitzschia
Pseudo-nitzschia
Pseudo-nitzschia
Pseudo-nitzschia
Pseudo-nitzschia
Pseudo-nitzschia
Pseudo-nitzschia
Alexandrium
Alexandrium
Alexandrium
Alexandrium
Alexandrium
Alexandrium
Alexandrium
Alexandrium
Alexandrium
Alexandrium
Alexandrium
Alexandrium
Alexandrium
Alexandrium
Alexandrium
Alexandrium
Alexandrium

\begin{tabular}{|c|c|}
\hline delicatissima & Gefosse G3 \\
\hline delicatissima & IFSG3 \\
\hline delicatissima & IFSG5 \\
\hline delicatissima & IFG2 \\
\hline delicatissima & IFG4 \\
\hline pseudodelicatissima & 205 PN-JF \\
\hline calliantha & 120 \\
\hline delicatissima & AR1 \\
\hline delicatissima & 171 \\
\hline $\begin{array}{l}\text { delicatissima } \\
\text { arenysensis }\end{array}$ & 161 \\
\hline $\begin{array}{l}\text { arenysensis } \\
\text { fraudulenta }\end{array}$ & AR3 \\
\hline galaxiae & 173 \\
\hline multistriata & 150 \\
\hline pungens & 143 \\
\hline minutum & AM89BM \\
\hline minutum & AM99PZ \\
\hline catenella & v676 \\
\hline catenella & v817 \\
\hline catenella & B9-1 \\
\hline catenella & C1-1 \\
\hline catenella & D3-1 \\
\hline catenella & A12-1 \\
\hline catenella & D9-1 \\
\hline catenella & C10-1 \\
\hline tamarense & ATT07 \\
\hline tamarense & H2-1 \\
\hline tamarense & A33 \\
\hline tamarense & $\mathrm{H} 4-2$ \\
\hline tamarense & B11-2 \\
\hline tamarense & $\mathrm{C} 12-1$ \\
\hline tamarense & B9-3 \\
\hline
\end{tabular}

France, Gefosse

France, St Germain de

Varreville

France, St Germain de

Varreville

France, Gefosse

France, Gefosse

France

France, Baie de Morlaix

France, Penzé

France, Etang de Thau

France, Etang de Thau

France, Etang de Thau
Caen University, France

Ifremer, France

Ifremer, France

Ifremer, France

Ifremer, France

Ifremer, France

Tarragona, IRTA

Tarragona, IRTA

Tarragona, IRTA

Tarragona, IRTA

Tarragona, IRTA

Tarragona, IRTA

Tarragona, IRTA

Tarragona, IRTA

Tarragona, IRTA

Tarragona, IRTA

Ifremer, France

Ifremer, France

Ifremer, France

Ifremer, France

Montpellier University, France

Montpellier University, France

Montpellier University, France

Montpellier University, France

Montpellier University, France

Montpellier University, France

Ifremer, France

Montpellier University, France

Montpellier University, France

Montpellier University, France

Montpellier University, France

Montpellier University, France

Montpellier University, France
J. Fauchot, M. Thorel

K. Andree

$\mathrm{K}$. Andree

$\mathrm{K}$. Andree

$\mathrm{K}$. Andree

$\mathrm{K}$. Andree

K. Andree

$\mathrm{K}$. Andree

$\mathrm{K}$. Andree

$\mathrm{K}$. Andree

K. Andree

M. Laabir

M. Laabir

M. Laabir

M. Laabir

M. Laabir

M. Laabir

M. Laabir

M. Laabir

M. Laabir

M. Laabir

M. Laabir

M. Laabir 


\begin{tabular}{|c|c|c|c|c|c|}
\hline Karenia & mikimotoi & GATIN95 & France & Ifremer, France & \\
\hline Karenia & selliformis & & France & Ifremer, France & \\
\hline Karenia & brevis & $\mathrm{sp} 3$ & & $\begin{array}{l}\text { Texas A \&M University, dept of } \\
\text { Oceanography, USA }\end{array}$ & L. Campbell \\
\hline Karenia & brevis & wilson & & $\begin{array}{l}\text { Texas A \&M University, dept of } \\
\text { Oceanography, USA }\end{array}$ & L. Campbell \\
\hline Karenia & brevis & sp1 & & $\begin{array}{l}\text { Texas A \&M University, dept of } \\
\text { Oceanography, USA }\end{array}$ & L. Campbell \\
\hline Karenia & mikimotoi & $\mathrm{C} 21$ & & $\begin{array}{l}\text { Texas A \&M University, dept of } \\
\text { Oceanography, USA }\end{array}$ & L. Campbell \\
\hline Prorocentrum & micans & & France & Ifremer, France & \\
\hline Prorocentrum & triestrum & & France & Ifremer, France & \\
\hline Prorocentrum & lima & PL2000 & France & Ifremer, France & \\
\hline Lingulodinium & polyedrum & VGO668 & France & Ifremer, France & \\
\hline Ostreopsis & ovata & IFR-OST & France & Ifremer, France & \\
\hline Vulcanodinium & rugosum & & France, Etang d'Ingril & Ifremer, France & \\
\hline Dinophysis & caudata & & & $\begin{array}{l}\text { Instituto Español de } \\
\text { Oceanografía Vigo, Spain }\end{array}$ & F. Rodriguez \\
\hline Dinophysis & acuminata & & & $\begin{array}{l}\text { Instituto Español de } \\
\text { Oceanografía, Vigo, Spain }\end{array}$ & F. Rodriguez \\
\hline Dinophysis & acuta & & & $\begin{array}{l}\text { Instituto Español de } \\
\text { Oceanografía, Vigo, Spain }\end{array}$ & F. Rodriguez \\
\hline Dinophysis & tripos & & & $\begin{array}{l}\text { Instituto Español de } \\
\text { Oceanografía, Vigo, Spain }\end{array}$ & F. Rodriguez \\
\hline Dinophysis & acuminata & D1 & France, Antifer & Ifremer, France & \\
\hline Dinophysis & acuminata & D2 & France, Antifer & Ifremer, France & \\
\hline Azadinium & spinozum & & & Ifremer, France & \\
\hline Chaetoceros & grande & & & Ifremer, France & \\
\hline Scripsiella & trochoidea & ST97PZ & France, Penzé & Ifremer, France & \\
\hline Tetraselmis & $s p$ & & & Ifremer, France & \\
\hline Skeletonema & costatum & & & Ifremer, France & \\
\hline
\end{tabular}


Table S2: Experimental validation of probe specificity. Fluorescence signal of single target hybridizations to the 81 validated probes. (A) Pseudo-nitzschia species; (B) various dinoflagellate species; (C) Alexandrium species. Probes showing no signal are not listed. Bold: values above the threshold.

\begin{tabular}{|c|c|c|c|c|c|c|c|c|c|c|c|c|}
\hline A) & P. delicatissima & $P$. arenysensis & $\begin{array}{r}P . \text { sp cuspidata/ } \\
\text { pseudodelicatissima }\end{array}$ & $P$. seriata & P. australis & P. americana & P. calliantha & P. fraudulenta & $P$. galaxiae & P. multiseries & P. multistriata & P. pungens \\
\hline PSN_gen_hf20 & 8914 & 6877 & 1045 & 16926 & 39580 & 19965 & 9168 & 7386 & 6852 & 4708 & 7082 & 39286 \\
\hline PSN_gen_hf8 & 10546 & 7666 & 11624 & 18569 & 40755 & 21099 & 12816 & 6527 & 17038 & 132 & 5155 & 39132 \\
\hline PSN_delicatGrp_ITS_5 & 4989 & 4613 & 39 & 83 & 136 & & 586 & & & & 82 & \\
\hline PSN_delicat_ITS_7 & 5689 & 560 & & & & & & 9 & 37 & & 89 & \\
\hline PSN_arenys_ITS_26 & & 46016 & & & & & & & & & & \\
\hline PSN_cuspidata_ITS_27 & & & 60539 & & & & & & & & 167 & \\
\hline PSN_pseudo_cuspi_ITS_2 & & & 6135 & & & & & & & & & \\
\hline PSN_pseudodelicat_ITS_20 & & & 159 & & & & & & & & & \\
\hline PSN_seriataGrp_f10 & & & & 65364 & 54598 & & & & & & & \\
\hline PSN_seriataGrp_f4 & & & & 65365 & 54663 & & & & & & & \\
\hline PSN_seriata_ITS_8 & & & & 8825 & 1382 & & & & & & & \\
\hline PSN_austr5-2m & & & & & 7946 & & & & & & & \\
\hline PSN_australis5M & & & & & 11848 & & & & & & & \\
\hline PSN_americana31m & & & & & & 65295 & & & & & & \\
\hline PSN_americana_f10 & & & & & & 6663 & & & & & & \\
\hline PSN_americana_ITS_8 & & & & & & 451 & & & & 422 & & \\
\hline PSN_calliantha_manii_ITS_30 & & & & & & & 4836 & & & & & \\
\hline PSN_calliantha3-1m & & & & & & & 3908 & & & & 13 & \\
\hline PSN_calliantha_ITS_19 & & & & 25 & & & 5628 & & & & 214 & \\
\hline PSN_fraudulenta1m & & & & & & & 153 & 63778 & & & & 57 \\
\hline PSN_fraudulenta_f13 & & & & & & & 52 & 27813 & 355 & & & \\
\hline PSN_fraudulenta_ITS_41 & & & & & & & 84 & 36123 & & & & \\
\hline PSN_fraudulenta_ITS_50 & & & & & & & & 9209 & & & & \\
\hline PSN_galax_decip_ITS_15 & & & & & & & & & 27471 & & & \\
\hline PSN_galaxiae_ITS_1 & & 103 & & & & & & & 3412 & & & \\
\hline PSN_galaxiae_ITS_6 & & & & & 8 & & & & 47120 & & & \\
\hline PSN_multiseries6 & & & & & & & & 135 & & 26733 & & \\
\hline PSN_multiseries_ITS_1 & 71 & 236 & & & & & & & & 3136 & & \\
\hline PSN_multiseries_ITS_13 & 36 & & & & & & & & & 8237 & & \\
\hline PSN_multistriata_f1 & & & & 22 & & & & 124 & & 315 & 35346 & \\
\hline PSN_multistriata_f9 & & & & & & 33 & & & & & 4869 & \\
\hline
\end{tabular}


PSN_pungens1-5bm

PSN_pungens_ITS_4

Vulcanodinium_ITS_4

KareITS 44

KarelTS_49

Kmiki_brev_ITS_38

Kmiki_brev_ITS_47

Kselli_brev_ITS 46

KmikiITS_23

Kbrevis_ITS_16

Amin2-

AminITS_18

AminITS_23

A_tamarenseGrp_ITS
34417

33577

1432

65177

65133

6573

177

172

141

435 


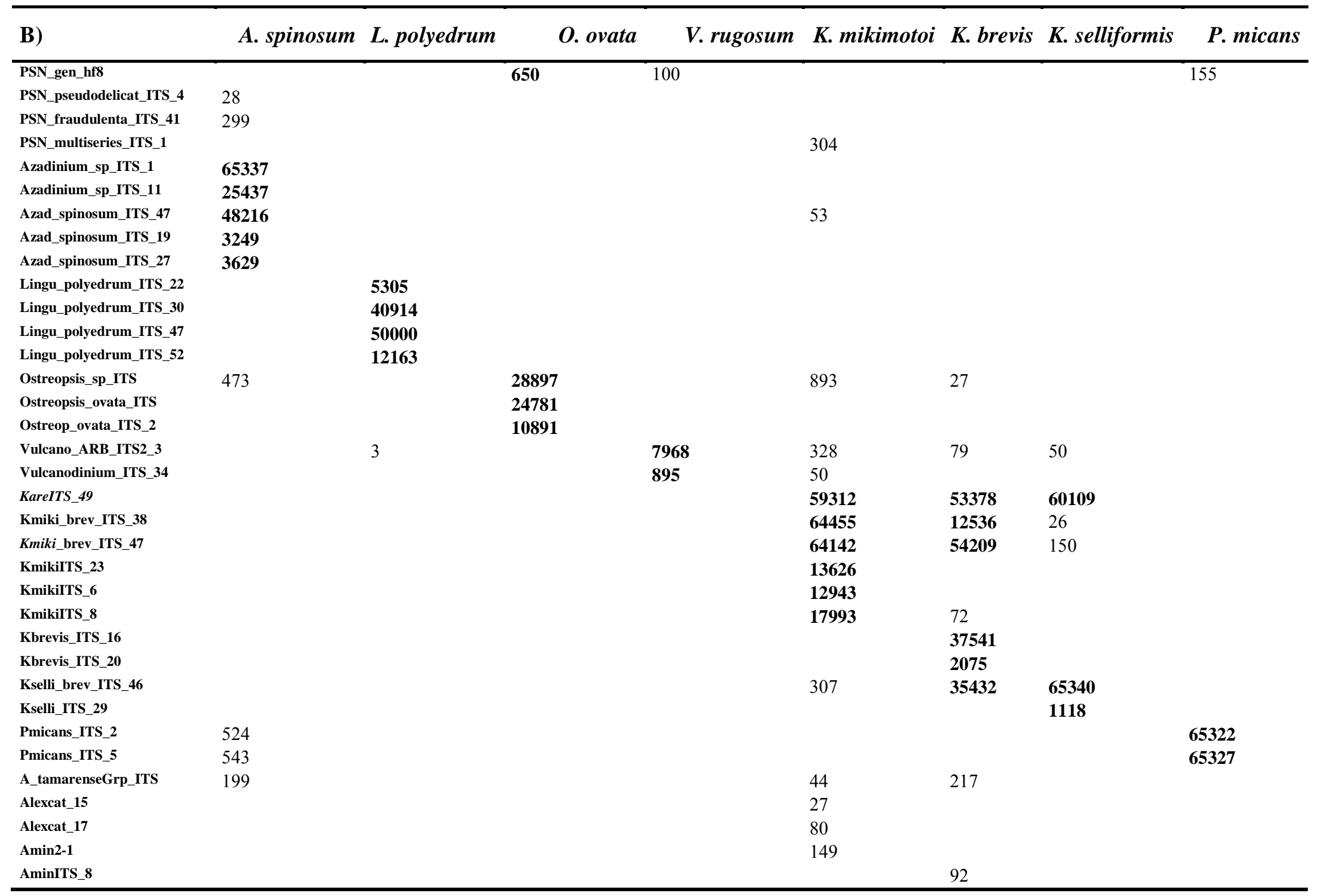




\begin{tabular}{|c|c|c|c|c|c|c|c|c|c|}
\hline \multirow[t]{2}{*}{ C) } & \multicolumn{3}{|c|}{$18 S$} & \multicolumn{3}{|c|}{$28 S$} & \multicolumn{3}{|c|}{ ITS } \\
\hline & A. minutum & A. catenella & A. tamarense & A. minutum & $\begin{array}{r}\text { A. catenella } \\
109\end{array}$ & $\begin{array}{r}\text { A. tamarense } \\
45\end{array}$ & A. minutum & $A$ & A. tamarense \\
\hline PSN_gen_hf20 & & 15 & & & & & 78 & 51 & 53 \\
\hline PSN_gen_hf8 & & & & & & & 19 & 64 & 22 \\
\hline PSN_delicatGrp_ITS_5 & & 67 & & & & & & & \\
\hline PSN_pseudodelicat_ITS_4 & & 90 & 104 & & & & & & \\
\hline PSN_seriataGrp_f4 & & 53 & & & & & & & \\
\hline PSN_seriata_ITS_8 & & 125 & & & & & & & \\
\hline PSN_americana31m & & 156 & & & & & 104 & 28 & \\
\hline PSN_fraudulenta_ITS_41 & & & & & & & & 10 & 14 \\
\hline PSN_fraudulenta1m & & & & & & & & 29 & 61 \\
\hline PSN_multiseries_f8 & & 50 & & & & & & & \\
\hline PSN_multiseries_ITS_1 & & 69 & & & & & & & \\
\hline PSN_multiseries_ITS_13 & 95 & 2940 & 2673 & & 6 & & & & \\
\hline Ostreopsis_sp_ITS & & & & & & & 33 & 812 & 319 \\
\hline Vulcanodinium_ITS_25 & & & & & & & 53 & & \\
\hline Vulcanodinium_ITS_4 & & & & & & & 57 & & \\
\hline KareITS_44 & & & & & & & & 190 & \\
\hline KareITS_49 & & & & & & & & 722 & \\
\hline Kselli_brev_ITS_46 & & & & & & & & 505 & \\
\hline Kselli_ITS_29 & & & & & & & & 82 & \\
\hline Pmicans_ITS_2 & & & & & & & 45 & & \\
\hline Alex_SILVA & 8423 & 17783 & 14052 & & & & & & \\
\hline Alex28S & & 43 & & 53577 & 65289 & 59391 & & 2 & \\
\hline $\begin{array}{l}\text { Aminutum_insuet_SILV }{ }_{5} \\
\text { - }\end{array}$ & 28673 & 66 & & & & & & & \\
\hline Aminutum_SILV_9 & 41907 & 142 & & & & & & & \\
\hline AminITS_23 & & & & & & & 65355 & 10 & \\
\hline AminITS_8 & & 57 & & & & & 10933 & & \\
\hline Amin_ITS_18 & & & & & & & 61080 & & \\
\hline Amin2-1 & & & & 2073 & & & & & \\
\hline Acat-tam_SILV_8 & & 60618 & 39343 & & & & & 19 & \\
\hline A_tamarenseGrp_SILV_5 & 1049 & 25667 & 19395 & & & & & & \\
\hline A_tamarenseGrp_ITS & & & & & & & 1554 & 33604 & 20820 \\
\hline Acatenella_SILV_6 & & 44666 & 1522 & & & & & & \\
\hline Alexcat_15 & & & & & 31551 & & & & \\
\hline Alexcat_17 & & & & & 60514 & 39 & & & \\
\hline Alex_tam11 & & & & & 149 & 1368 & & & \\
\hline
\end{tabular}



Table S3: Identification of Pseudo-nitzschia species by the Phytochip in environmental samples collected in the Bay of Concarneau. FS value in bold: values above of the threshold.

\begin{tabular}{|c|c|c|c|c|c|c|c|}
\hline Samples & & BC2 & BC6 & BC12 & BC18 & BC21 & $\mathrm{BC26}$ \\
\hline \multirow[t]{3}{*}{ Target Species } & Probes & & & & & & \\
\hline & PSN_genus_hf20 & 9509 & 10852 & 3327 & 8605 & 12784 & 9530 \\
\hline & PSN_genus_hf8 & 7554 & 12421 & 4529 & 10455 & 16108 & 12329 \\
\hline $\begin{array}{l}\text { P. delicatissimal } \\
\text { arenysensis/ } \\
\text { micropora }\end{array}$ & PSN_delicatGrp_ITS_5 & 155 & 5541 & 155 & 87 & 125 & 796 \\
\hline \multirow{2}{*}{$\begin{array}{l}\text { P. delicatissima } \\
\text { P. arenysensis }\end{array}$} & PSN_delicatissima_ITS_7 & 78 & 5212 & 91 & 48 & & 372 \\
\hline & PSN_arenysensis_ITS_26 & & 849 & & & & 1570 \\
\hline \multirow{4}{*}{$\begin{array}{l}\text { P. cuspidata. } \\
\text { pseudodelicatissima }\end{array}$} & PSN_cuspidata_ITS_27 & 13679 & 5751 & 769 & 8263 & 22758 & 6624 \\
\hline & PSN_pseudo_cuspi_ITS_2 & 7118 & 4551 & 1537 & 5634 & 7670 & 3061 \\
\hline & PSN_pseudodelicat_ITS_20 & 1901 & 1528 & 129 & 1624 & 2165 & 838 \\
\hline & PSN_pseudodelicat_ITS_4 & 1925 & 1367 & & 1435 & 2523 & 845 \\
\hline \multirow{2}{*}{ P. seriata/ australis } & PSN_seriataGrp_f10 & 133 & & & & & \\
\hline & PSN_seriataGrp_f4 & 10 & & & & & \\
\hline \multirow{2}{*}{ P. australis } & PSN_australis5-2m & 257 & & & & & \\
\hline & PSN_australis5M & 274 & & & & & \\
\hline \multirow{2}{*}{ P. americana } & PSN_americana $31 \mathrm{~m}$ & & & & & & 175 \\
\hline & PSN_americana_f10 & & & & & & \\
\hline \multirow{4}{*}{ P. fraudulenta } & PSN_fraudulenta1m & 16455 & 381 & 2341 & 9123 & 6209 & 11196 \\
\hline & PSN_fraudulenta_f13 & 4914 & 75 & 534 & 2658 & 2364 & 2992 \\
\hline & PSN_fraudulenta_ITS_41 & 6664 & 128 & 1308 & 4057 & 2742 & 4589 \\
\hline & PSN_fraudulenta_ITS_50 & 1530 & & 280 & 1115 & 843 & 1307 \\
\hline \multirow{3}{*}{ P. pungens } & PSN_pungens_p1 & & & 1052 & 1505 & & 2950 \\
\hline & PSN_pungens1-5bm & & & 2492 & 3289 & & 6068 \\
\hline & PSN_pungens_ITS_4 & & & 3843 & 4318 & & 7225 \\
\hline \multirow{6}{*}{$\begin{array}{l}\text { Species not } \\
\text { experimentally } \\
\text { validated }\end{array}$} & PSN_dolorosa_ITS_36 & & & & & & \\
\hline & PSN_dolorosa_ITS_44 & & 180 & & & & \\
\hline & PSN_heimii_f18 & & & & & & 80 \\
\hline & PSN_heimii_ITS_12 & 21 & 33 & & & & 264 \\
\hline & PSN_heimii_ITS_6 & & & 28 & & & 169 \\
\hline & PSN_subpacifiqua_f6 & 71 & & & & & 315 \\
\hline
\end{tabular}


Fig. S1.

Evidence of a "Position Of Label" (POL) effect. A) Schematic representation of hybrid pairs on the chip surface is shown for four hybridization positions. PSN_fraudulenta1m, PSN_fraudulenta_ITS_41, PSN_fraudulenta_f13 and PSN_fraudulenta_ITS_50 probes (in black) are spotted. The fluorescent Cy5 label located at the $5^{\prime}$ end of the DNA target (i.e. $P$. fraudulenta species - in red) is indicated as a star. Four pairs of hybridization spots are shown for the different probes. The distance between the Cy5 label and the oligonucleotide probe, which clearly influences the fluorescent signal, are graphically represented. Larger distances lead to weaker signals. B) Relationship between the FS and the distance between the fluorescent label and the oligonucleotide probes based on 25 Pseudo-nitzschia probes from 7 species for which we have at least 3 specific probes. Species probes were separately analyzed to limit the nucleotide composition effect. Relationships were significant except for Pseudo-nitzschia calliantha.

A
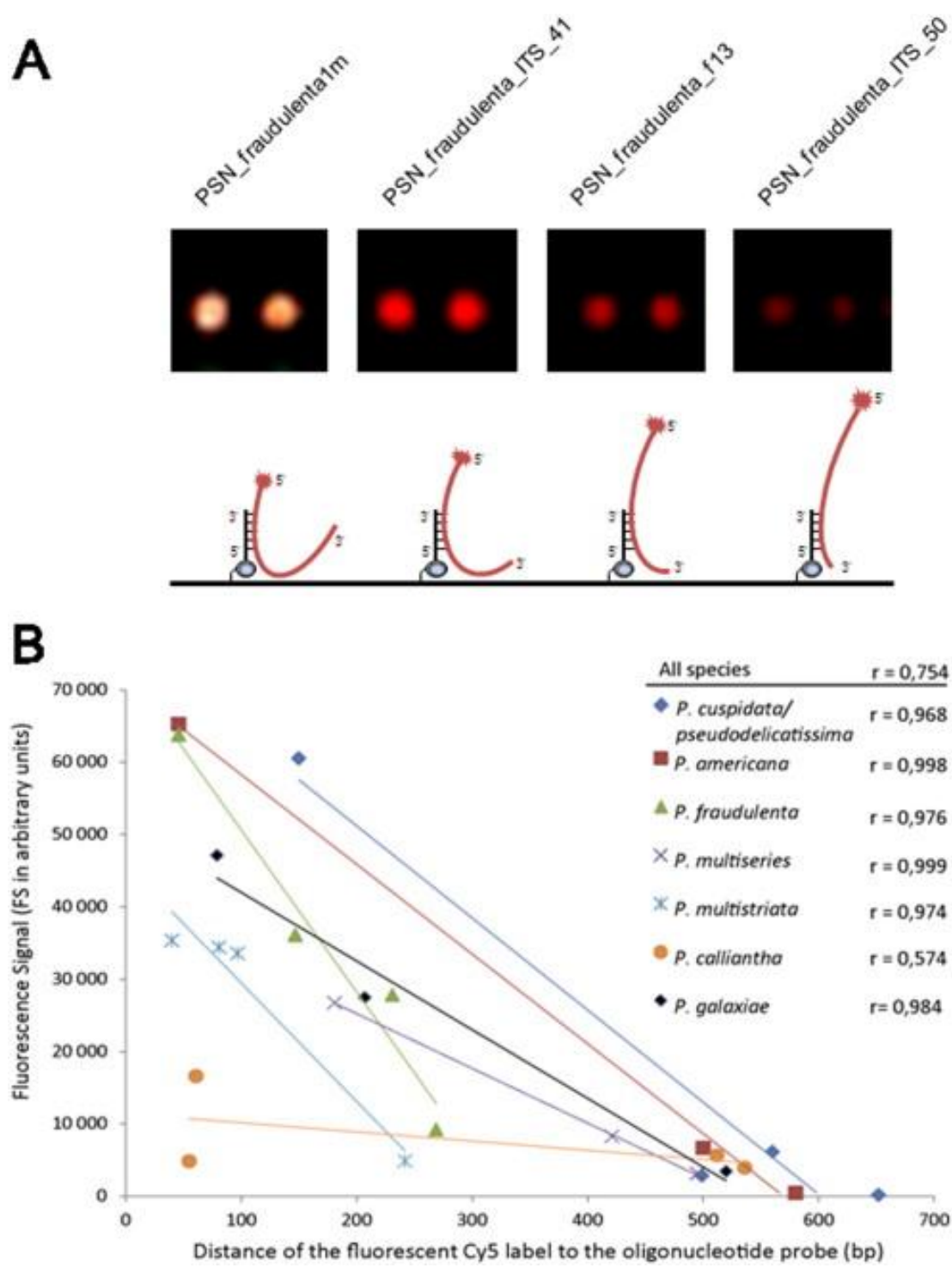